\title{
THE PARTIAL-CLOSING CONUNDRUM: THE DUTY OF EMPLOYERS AND UNIONS TO BARGAIN IN GOOD FAITH
}

\author{
Timothy J. HeINSZ*
}

Since 1935 collective bargaining has been the cornerstone of industrial relations for millions of American workers. ${ }^{1}$ The purpose of the National Labor Relations Act (NLRA) ${ }^{2}$ is to eliminate industrial strife between companies and unions through labor negotiations. ${ }^{3}$ The Wagner $\mathrm{Act}^{4}$ requires employers to bargain with the majority representative of their employees; 5 the Taft-Hartley Amendments ${ }^{6}$ place a correlative bargaining obligation upon unions. ${ }^{7}$ Congress has defined the duty to bargain as "the mutual obligation of the employer and the representative of the einployees to ineet at reasonable times and confer in good faith with respect to wages, hours, and other terms and conditions

* Associate Professor of Law, University of Toledo College of Law. A.B. 1969, St. Louis University; J.D. 1972, Cornell Law School. The author would like to express his appreciation to his research assistant, Tom Dixon.

1. As of 1978, union membership for non-agricultural employees totalled 20.2 million and was approximately $23.6 \%$ of the entire non-agricultural work force. Gov'T EMPL. REL. REP. (BNA), No. 827, at 35 (Sept. 10, 1979). The exact percentage of workers covered by collective bargaining agreements is unknown. In 1974 labor contracts negotiated by unions and employee associations in the United States and Canada covered 24.7 million employees. U.S. BUREAU OF Labor Statistics, Dep't of Labor, BUll. No. 1937, Directory of National Unions aND EMPLOYEES AsSOCIATIONS 79 n.2 (1975).

2. 29 U.S.C. $\$ \S 151-169$ (1976 \& Supp. II 1978).

3. Section 1 of the Act provides:

It is hereby declared to be the policy of the United States to eliminate the causes of certain substantial obstructions to the free flow of commerce and to mitigate and eliminate these obstructions when they have occurred by encouraging the practice and procedure of collective bargaining and by protecting the exercise by workers of full freedom of association, self-organization, and designation of representatives of their own choosing, for the purpose of negotiating the terms and conditions of their eniployment or other inutual aid or protection.

29 U.S.C. § 151 (1976).

4. Pub. L. No. 74-198, 49 Stat. 449 (1935) (codified in 29 U.S.C. $\$ 8151-169$ (1976)).

5. Section 8(a)(5) provides: "It shall be an unfair labor practice for an employer-... (5) to refuse to bargain collectively with the representatives of his employees, subject to the provisions of section 9(a)." 29 U.S.C. \& 158(a)(5) (1976).

6. Pub. L. No. 80-101, 61 Stat. 136 (1947) (codifled in 29 U.S.C. $\$ \S 141-144,151-167,171$ 187 (1976)).

7. Section $8(b)(3)$ provides: "It shall be an unfair labor practice for a labor organization or its agents- . . (3) to refuse to bargain collectively with an employer, provided it is the representative of his employees subject to the provisions of section 159(a) . . ." 29 U.S.C. \& 158(b)(3) (1976). 
of employment . . ..."8

The success of collective bargaining in improving employees' working conditions and in peacefully resolving disputes between management and labor is reflected in the increasing number of items over which the National Labor Relations Board (NLRB) and the courts have required parties to negotiate. 9 Today employers and unions are required to bargain over such diverse matters as compensation, ${ }^{10}$ severance pay, ${ }^{11}$ pension and other welfare plans, ${ }^{12}$ profit-sharing plans, ${ }^{13}$ stock purchase plans, ${ }^{14}$ company housmg, ${ }^{15}$ meals and discounts, ${ }^{16}$ grievance and arbitration procedures, ${ }^{17}$ layoffs and recalls, ${ }^{18}$ dis-

8. Section 8(d), id. § 158(d).

9. Bargaining issnes are classified as mandatory, permissive, or illegal subjects of bargaining: R. Gorman, Labor LAW 496-531 (1976); C. MoRrus, THe DeVEloping Labor LAW 389439 (1971). Mandatory items of bargaining fall within the terms "wages, hours . . . and conditions of employment" under section 8(d), 29 U.S.C. \& 158(d) (1976); parties must negotiate over such issues in good faith to impasse under section 8(a)(5), id. \& 158 (a)(5), and section 8(b)(3), id. $\S 158$ (b)(3). The parties may propose permissive subjccts of bargaining but cannot lawfully insist upon them as a condition to a collective bargaining agreement. NLRB v. Wooster Div. of BorgWarner Corp., 356 U.S. 342 (1958); Industrial Union of Marine Workers v. NLRB, 320 F.2d 615 (3d Cir. 1963), cert. denied, 375 U.S. 984 (1964). Issues are illegal subjects of bargaining if inclusion of the items in a labor contract would be unlawful or imconsistent with the policies of the NLRA. See, e.g., Hughes Tool Co., 147 N.L.R.B. 1573 (1964) (declaring invalid a contract clause discriminating between white and black workers). See generally Fleming, The Obligation to Bargain in Good Faith, 47 VA. L. Rev. 988 (1961); Murphy, Impasse and the Duty to Bargain in Good Faith, 39 U. PITT. L. REv. 1 (1977); Note, Application of the Mandatory-Permissive Dichotomy to the Duty to Bargain and Unilateral Action: A Review and Reevaluation, 15 WM. \& MARY L. REv. 918 (1974).

10. See, e.g., C \& S Indus., 158 N.L.R.B. 454 (1966) (piece rates and imcentive plans); Smith Cabinet Mfg. Co., 147 N.L.R.B. 1506 (1964) (shift differentials).

11. See NLRB v. Adams Dairy, Inc., 322 F.2d 553 (8th Cir. 1963), vacated, 379 U.S. 644 (1965), on remand, 350 F.2d 108 (8th Cir. 1965), cert. denied, 382 U.S. 1011 (1966).

12. See, e.g., Carpenter Sprinkler Corp., 238 N.L.R.B. No. 139, 99 L.R.R.M. 1356 (1978), enforced, 605 F.2d 60 (2d Cir. 1979) (substitution of the einployer's pension, health, and welfare benefits for those provided under an expired contract); Keystone Consol. Indus., 237 N.L.R.B. 763 (1978), enforced, 606 F.2d 171 (7th Cir. 1979) (change in the administrator-processor of the employer's hospital, medical, and surgical imsurance plan in the labor contract); Inland Steel Co., 77 N.L.R.B. 1, enforced, 170 F.2d 247 (7th Cir. 1948) (pension benefits), cert. denied, 336 U.S. 960 (1949).

13. Sce, e.g., Winn-Dixie Stores, Inc. v. NLRB, 567 F.2d 1343 (5th Cir. 1978), cert. denied, 439 U.S. 985 (1978); Dickten \& Masch Mfg. Co., 129 N.L.R.B. 112 (1960).

14. See, e.g., Winn-Dixie Texas, Inc. (Foodway), 234 N.L.R.B. 72 (1978); B.F. Goodrich Co., 195 N.L.R.B. 914 (1972).

15. See, e.g., NLRB v. Lehigh Portland Cement Co., 205 F.2d 821 (4th Cir. 1953); Elgin Standard Brick Mfg. Co., 90 N.L.R.B. 1467 (1950).

16. See, e.g., Ford Motor Co. v. NLRB, 441 U.S. 488 (1979); NLRB v. Central Ill. Pub. Serv. Co., 324 F.2d 916 (7th Cir. 1963); Chemtromics, Inc., 236 N.L.R.B. 178 (1978).

17. See, e.g., NLRB v. Montgomery Ward \& Co., 133 F.2d 676 (9th Cir. 1943); NLRB v. Boss Mfg. Co., 118 F.2d 187 (7th Cir. 1941); Peerless Food Products, Inc., 236 N.L.R.B. 161 (1978).

18. See, e.g., Awrey Bakeries, Inc. v. NLRB, 548 F.2d 138 (6th Cir. 1976); Master Slack 
charge, ${ }^{19}$ work loads, ${ }^{20}$ work rules, ${ }^{21}$ work assignments, ${ }^{22}$ compulsory retirement policies, ${ }^{23}$ no-strike clauses, ${ }^{24}$ safety, ${ }^{25}$ and contractual clauses concerning race and sex discrimination. ${ }^{26}$

Despite these many areas of agreement, the NLRB and the courts contimue to differ over whether structural changes in an einployer's busmess, sucl as relocations, liquidations of certain lines of busmess, and partial closings, slould be mandatory subjects of bargaining. ${ }^{27}$ For the most part, the NLRB lias taken an approacli opposite to that of the majority of appellate courts over the duty to negotiate im partial-closing situations. Whereas the Board requires an einployer to notify and to bargaim with a union over both the decision and effects of a partial closing, ${ }^{28}$ the appellate courts have lield that the duty exists only witl regard to the effects of the closing and that the decision to close is an inherent management prerogative. ${ }^{29}$ The conflict is particularly dis-

Corp., 230 N.L.R.B. 1054 (1977), enforced, 618 F.2d 6 (6th Cir. 1980).

19. See National Licorice Co. v. NLRB, 309 U.S. 350 (1940); NLRB v. Bachelder, 120 F.2d 574 (7th Cir.), cert. denied, 314 U.S. 647 (1941).

20. See, e.g., Irvinton Motors, Inc., 147 N.L.R.B. 565, enforced, 343 F.2d 759 (3d Cir. 1965); Little Rock Downtowner, Inc., 145 N.L.R.B. 1286 (1964), enforced, 34I F.2d 1020 (8th Cir. 1965).

21. See NLRB v. Southern Transp., Inc., 343 F.2d 558 (8th Cir. 1965); Tower Hosiery Mills, Inc., 81 N.L.R.B. 658 (1949), enforced, 180 F.2d 701 (4th Cir.), cert. denied, 340 U.S. 811 (1950); Timken Roller Bearing Co., 70 N.L.R.B. 1500 (1946), enforcement denied on other grounds, 161 F.2d 949 (6th Cir. 1947).

22. See Kendall College, 228 N.L.R.B. 1083 (1977), enforced, 570 F.2d 216 (7th Cir. 1978).

23. See Inland Steel Co., 77 N.L.R.B. 1, enforced, 170 F.2d 247 (7th Cir. 1948), cert. denied, 356 U.S. 960 (1949).

24. See Shell Oil Co., 77 N.L.R.B. 1306 (1948).

25. See, e.g., Fibreboard Paper Prods. Co. v. NLRB, 379 U.S. 203, 222 (1964); J.P. Stevens \& Co., 239 N.L.R.B. 738 (1978), enforced, 623 F.2d 322 (4th Cir. 1980).

26. See Wichita Eagle \& Beacon Publishing Co., 222 N.L.R.B. 742 (1976); Jubilee Mfg. Co., 202 N.L.R.B. 272 (1973), affd, 87 L.R.R.M. 3 I68 (D.C. Cir. 1974).

27. C. MoRris, supra note 9, at 418-22; Bliss, Labor's Plant Closure Pains, 24 Sw. L.J. 259 (1970); Fastiff, Changes in Business Operations: The Effects of the NLRA and Contract Language on Employer Authority, 14 SANTA ClaRA L. Rev. 281 (1974); Goetz, The Duty to Bargain About Changes in Operations, 1964 DUKE L.J. 1; Rabin, Fibreboard and the Termination of Bargaining Unit Work: The Search for Standards in Defining the Scope of the Duty to Bargain, 71 CoLUM. L. REv. 803 (1971); Schwarz, Plant Relocation or Partial Termination-The Duty to Decision-Bargain, 39 Fordham L. Rev. 8 I (1970); Swift, Plant Relocation: Catching Up With the Runaway Shop, 14 B.C. IND. \& CoM. REv. 1135 (1973).

28. See text accompanying notes 70-72 \& 96 infra.

29. See text accompanying notes $59-69$ \& 74 infra. "Effects" bargaining usually involves rights of employees that arise as a result of a closing, such as severance pay, pensions, other accrued benefits, seniority, dates for unemployment eligibility, pending grievances, and possible reemployment in other parts of an employer's enterprise. See Royal Typewriter Co. v. NLRB, 533 F.2d 1030, 1039 (8th Cir. 1973); NLRB v. Royal Plating \& Polishing Co., 350 F.2d 191, 196 (3d Cir. 1965). See also Morrison Cafeterias Consol. v. NLRB, 431 F.2d 254 (8th Cir. 1970); NLRB v. Drapery Mfg. Co., 425 F.2d 1026 (8th Cir. 1970); NLRB v. Thompson Transp. Co., 406 F.2d 698 (10th Cir. 1969); NLRB v. Transmarine Navigation Corp., 380 F.2d 933 (9th Cir. 1967). 
turbing in view of the number of structural business changes in recent years. ${ }^{30}$ As more companies acquire, merge with, and liquidate business enterprises, and as recessions force many companies to close operations and lay off employees, the question of the duty to bargam over these actions becomes increasingly important.

Not only have the Board and the courts differed in the past over the duty to bargain, but also they are presently shifting their positions. The Board seems to be requiring less bargaining over closing decisions, ${ }^{31}$ while some courts recently have required more bargaining. ${ }^{32}$ The resulting uncertainty is not just a matter of scholarly concern. Employees and unions have little idea whether they will be consulted before jobs are lost and livelihoods disrupted. Similarly, employers who guess wrong, and fail to bargain when they should have, face severe penalties. ${ }^{33}$ The Supreme court will soon have the opportunity to resolve these uncertainties in First National Maintenance Corp. $v$. $N L R B .^{34}$

This article first reviews the pertinent Board and court decisions concerning business hquidations. It points out the differences between

As the Board has noted, it is often difficult to distinguish clearly issues appropriate for "decision" as opposed to "effects" bargaining in a partial-closing case. See Ozark Trailers, Inc., 161 N.L.R.B. 561,570 (1966). For exainple, the amount of severance pay and accrued benefits due upon closing, or the tining and implementation of a closing, inight not only have an effect on the einployees, but might also influence the decision itself.

30. There were a great number of mergers, acquisitions, and business terminations in the mid-1970s:

\begin{tabular}{|c|c|c|}
\hline YEAR & $\begin{array}{l}\text { NUMBER OF MERGERS } \\
\text { AND ACQUISITIONS }\end{array}$ & $\begin{array}{l}\text { NUMBER OF INDUSTRIAL } \\
\text { AND COMMERCIAL FAILURES }\end{array}$ \\
\hline 1974 & 1,460 & 9,915 \\
\hline $1975 \ldots \ldots \ldots \ldots \ldots$ & 1,048 & 11,432 \\
\hline $1976 \ldots \ldots \ldots \ldots \ldots \ldots$ & 1,081 & 9,628 \\
\hline $1977 \ldots \ldots \ldots \ldots \ldots \ldots$ & 1,182 & 7,919 \\
\hline
\end{tabular}

L. Leviton, FTC Statistical Report on Mergers and ACQuisitions 10 (1977); BUREau of the Census, United States Dep't of Com., Statistical Abstract of the United States: 1979 , at $574,576$.

31. See notes $98-101$ \& 105-19 infra and accompanying text.

32. See notes 120-24 infra and accompanying text.

33. See notes $91-95$ infra and accompanying text.

34. 627 F.2d 596 (2d Cir. 1980), cert. granted, 49 U.S.L.W. 3480 (U.S. Jan. 13, 1981) (No. 80544). In First National Maintenance, the company, which provided cleaning services to various nursing hounes, discontinued service to one hoine and disınissed the workers employed there without notifying the union that represented these employees. The Second Circuit affirmed the Board's finding that this action violated section 8(a)(5). The court applied the rebuttable-presumption analysis of Brockway Motor Trucks v. NLRB, 582 F.2d 720 (3d Cir. 1978), but unlike the Third Circuit, the court focused not on the interests of the parties but on the statutory purposes of the NLRA in imposing bargaining obligations. Because bargaining could have infiuenced the closing decision and because the company failed to show futihty or dire financial emergency, the court found a violation. 
the Board and the courts regarding when the duty to bargain over a decision to terminate part of a business enterprise arises, what the nature and extent of the duty are, and what the remedies for a failure to bargain properly are. The article then criticizes the approaches taken by the Board and the courts in these partial shutdown cases. Finally, the article suggests an alternative analysis for determining when the duty to bargain should arise in a partial closing.

\section{Court and Board Decisions}

The dichotoiny between the approaches of the NLRB and the courts of appeals can be traced to two Supreine Court decisions: Fibreboard Paper Products Corp. v. NLRB, ${ }^{35}$ decided in 1964, and Textile Workers Union v. Darlington Manufacturing Co. ${ }^{36}$ decided in 1965. In Fibreboard, during the renegotiation of a collective bargaining agreement between the company and the union that represented inaintenance employees at the company's plant, management announced that it had decided to subcontract out all the work then being performed by the maintenance employees. There was no proof that the company was motivated by anti-union sentiment; it simply wanted to save costs and to increase efficiency. The company hired an independent contractor to perforn the work on a cost-plus basis, and the contractor used the same equipment and supervisors, and perforned the saine work im the plant, as had the forner employees. The Board concluded, ${ }^{37}$ on the basis of its decision in Town \& Country Manufacturing Co.,$^{38}$ that the employer's failure to negotiate with the union over its

35. 379 U.S. 203 (1964).

36. 380 U.S. 263 (1965).

37. 138 N.L.R.B. 550, 551 (1962) enforced sub nom. Machinists Local 1304 v. NLRB, 322 F.2d 411 (D.C. Cir. 1963), affd 379 U.S. 203 (1964).

38. 136 N.L.R.B. 1022 (1962), enforced, 316 F.2d 846 (5th Cir. 1963). Initially the Board had held that there is no duty to bargain over an employer's decision to subcontract work. See, e.g., Fibreboard Paper Prods. Corp., 130 N.L.R.B. 1558 (1961). The Board reversed this policy in the Town \& Country case, 136 N.L.R.B. at 1027-28, relying primarily on Order of R.R. Telegraphers v. Chicago \& N.W. Ry., 362 U.S. 330 (1960). The Telegraphers case arose under the Railway Labor Act, 45 U.S.C. $\$ \S 151-163$, 181-188 (1976), which contains bargaining provisions similar to the NLRA. In that case the union threatened to strike over the employer's refusal to bargain about a proposed contractual amendment requiring union consent before the railroad could eliminate any employee positions or close any railroad stations. The employers sought an mjunction im federal court prohibiting such a strike. The Supreme Court held that no injunction could issue under the Norris-LaGuardia Act, 29 U.S.C. $\$ \S 101-115$ (1976), because a "labor dispute" was involved concerning a "condition of employment." 362 U.S. at 335. The Court also noted that the possible elimination of jobs could be the subject of bargaining under the Railway Labor Act because a loss of jobs is a "working condition" over which employers were required to bargain. Id. at 336. In Town \& Country the Board held that because the NLRA requires similar bargaining over the terms and conditions of employment, the decision to eliminate jobs through subcontracting was a subject over which employers were required to bargain. 136 N.L.R.B. at 1026. Some 
decision to subcontract out the work violated its duty to bargain under section $8(a)(5) .39$

The Supreme Court agreed with the Board in a decision authored by Chief Justice Warren. The opinion contained both expansive language, which the Board would later use in the partial-closing cases, and more limited statements, which appellate courts would seize upon to narrow and distimguish the case. First, the Fibreboard opinion noted that the subcontracting in the case caused the termination of jobs of bargaining-unit employees. The Court believed that employee dismissals plainly fell within the language of section $8(d)^{40}$ as a "condition of employment" over which an employer is required to bargain.41 The Court then concluded that requiring an employer to bargam would promote the central goals of the NLRA, underscoring this conclusion with a finding that many collective bargaining agreements contamed clauses concerning subcontracting and that the reasons for Fibreboard's subcontractimg - to reduce costs attributable to wages, fringe benefits, and excessive overtime-involved items usually resolved in collective bargaining.

Yet the Chief Justice noted several times that the Court's opinion was limited to "the facts of this case":42

The facts of the present case illustrate the propriety of submitting the dispute to collective negotiation. The Company's decision to contract out the maintenance work did not alter the Company's basic operation. The maintenance work still had to be performed in the plant. No capital investment was contemplated; the Company merely replaced existing employees with those of an independent contractor to do the same work under similar conditions of employment. Therefore, to require the employer to bargain about the matter would not significantly abridge his freedom to manage the busmess. ${ }^{43}$

The Court then affirmed the Board's remedy that the employer resume the maintenance operation, reinstate the employees with back pay from the date of the Board's decision, and fulfill its statutory duty to bargain.

courts and commentators have distinguished Telegraphers on the basis that the Railway Labor Act restricts management's rights more than the NLRA and that Telegraphers is inconsistent with prior and subsequent NLRB and appellate court decisions. See NLRB v. Adams Dairy, Inc., 322 F.2d 553 (8th Cir. 1963), vacated, 379 U.S. 644 (1965), on remand, 350 F.2d 108 (8th Cir. 1965), cert. denied, 382 U.S. 1011 (1966); Goetz, supra note 27, at 10-14.

39. 29 U.S.C. \& 158(a)(5) (1976). See note 5 supra.

40. 29 U.S.C. $\S 158$ (d) (1976). See text accompanying note 8 supra.

41. 379 U.S. at 209-10. The Court also cited Order of R.R. Telegraphers v. Chicago \& N.W. Ry., 362 U.S. 330 (1960), for the proposition that loss of employment as a result of contracting out work is a "condition of employment" under section 8(d) of the NLRA. See note 38 supra.

42. 379 U.S. at $209,214-15$.

43. $J d$. at 213. 
In his concurring opinion, Justice Stewart narrowed the holding. 44 He emphasized that the case involved a inere "substitution of one group of workers for another." 45 Other types of subcontracting practices or investinent decisions would not be subject to the duty to bargain. ${ }^{46}$ Although Justice Stewart agreed that job losses caused by technological change or other management investınent decisions could have a "cruel impact upon the lives and fortunes of the working inen and women of the Nation," he asserted that, in the absence of specific congressional authorization to the contrary, such decisions were strictly management prerogatives. ${ }^{47}$

Thus, although Fibreboard established the principle that the duty to bargain attaches to certain managenent decisions about operational changes, the decision's scope was far from clear. The Court acknowledged the imterest of employees in having some input prior to a decision resulting im the termination of jobs, but realized that it was treading close to the heart of management prerogatives. The majority opimon cautioned that the law in this area should be developed on a case-by-case basis. ${ }^{48}$

One year after Fibreboard the Supreme Court decided Textile Workers Union v. Darlington Manufacturing Co. ${ }^{49}$ The case involved the Deering-Milliken textile enterprise and the unionization of one of its plants, the Darlington Manufacturing Company. The Textile Workers Umion won a representation election at the South Carolina plant and asked the company to bargam. On the very day of the union's request the company's board of directors voted to close the plant. Shortly thereafter the company fired all employees at the plant and sold the machinery and equipment. The NLRB found that the closing was motivated by the anti-union feelings of Roger Milliken, the president of Darlington, and was thus unlawful. ${ }^{50}$ Although the Supreme Court decided the case under section 8(a)(3), ${ }^{51}$ which prohib-

44. Id. at 217 (Stewart, J., concurring).

45. Id. at 224 (Stewart, J., concurring).

46. Id at 225 (Stewart, J., concurring).

47. Id. at 225-26 (Stewart, J., concurring). For a very different view of the duty to bargain over the effects of technological change, see NLRB v. International Longshoremen's Ass'n, $100 \mathrm{~S}$. Ct. 2305, 2317 (1980) (there exists a "congressional preference for collective bargaining as the method for resolving disputes over dislocations caused by the introduction of technological innovation in the workplace"). See also National Woodwork Mfrs. Ass'n v. NLRB, 386 U.S. 612 (1967); American Newspaper Publishers Ass'n v. NLRB, 345 U.S. 100 (1953).

48. 379 U.S. at 215.

49. 380 U.S. 263 (1965).

50. 139 N.L.R.B. 241 (1962).

51. 29 U.S.C. \& 158(a)(3) (1976), which provides: "It shall be an unfair labor practice for an employer - . . (3) by discrimination in regard to hire or tenure of employment or any term or 
its an employer from encouraging or discouraging union membership by discriminatory treatment of employees, rather than under section 8(a)(5), the case has had a significant impact on an employer's duty to bargaim before a closing of operations. ${ }^{52}$

The Court first held that an employer has an absolute right to close its busmess completely-even if management chants anti-union mantras as it closes the doors..$^{53}$ Just as an employee can withdraw fron the coverage of the NLRA by quitting his job, an employer can remove itself from the coverage of the Act by ceasing to do business. The Court reasoned that an employer, even if motivated by spite for the union, can obtain no future business benefit by completely closing its enterprise. ${ }^{54}$ But a partial closing, the Court found, is subject to section 8(a)(3), because an anti-union partial closing can bring the employer future benefits by intimidating employees in the employer's other plants. 55

The Darlington Court then delineated specific rules for the Board to follow before finding an unfair labor practice "[i]n an area which trenches so closely upon otherwise legitimate employer prerogatives." 56 To establish a violation of section 8(a)(3), the Board must find that the employer had an interest or affiliation in another business, that the effect of the closing was to chill uniomism in that other business, and that the employer could reasonably foresee that the anti-union effects would occur. ${ }^{57}$ The requirements of effect and foreseeability have not often

condition of einployment to encourage or discourage inembership in any labor organization ...."

52. The Board had found that the coinpany violated section $8(a)(1), 29$ U.S.C. $\& 158(a)(1)$ (1976), by dismissing the employees after the decision to close, and that it violated section 8(a)(5), id. $\$ 158(\mathrm{a})(5)$ by refusing to honor the union's request to bargain after the decision to liquidate. The Court eliminated any consideration of sections $8(a)(1)$ and $(5)$, however, by noting that the propriety of the Board's conclusion about these violatious turned on whether the decision to shut down transgressed section 8(a)(3), id. § 158(a)(3). 380 U.S. at 266-67 nn.5 \& 6. According to the Court, the Board should be "treating the closing only under $\$ 8(a)(3)$." Id. at 268-69.

53. 380 U.S. at 273-74.

54. Id. at 269-74. In view of the Darlington decision, the Board has conceded that no duty exists to bargain over a decision to close completely. See, e.g., Midland-Ross Corp., 239 N.L.R.B. 323, 329 (1978), enforced, 617 F.2d 977 (3d Cir.), cert. denied, 101 S. Ct. 210 (1980). The Board, however, requires an employer to give notice and to bargain over the "effects" of a total shut down. Hillcrest Furniture Mfg., 253 N.L.R.B. No. 9, 105 L.R.R.M. 1393, 1394 (1980); Merryweather Optical Co., 240 N.L.R.B. 1213 (1979); J-B Enterprises, 237 N.L.R.B. 383 (1978); Stagg Zipper Corp., 222 N.L.R.B. 1249 (1976); Automation Inst. of L.A., Inc., 208 N.L.R.B. 725 (1974); Triplex Oil Refining Div. of Pentalic Corp., 194 N.L.R.B. 500 (1971); Interstate Tool Co., 177 N.L.R.B. 686 (1969).

55. 380 U.S. at 274-76.

56. Id. at 276 .

57. The Court described the test as follows:

If the persons exercising control over a plant that is being closed for anti-union reasons (1) have an interest in another business, whether or not affiliated with or engaged in the 
been met in subsequent cases. ${ }^{58}$ Moreover, the appellate courts have seized upon the broad language in Darlington regarding an employer's right to close its business, to determine whether an employer has a duty to bargain in such situations.

In 1965, the same year that the Supreme Court decided Darlington, the Courts of Appeals for the Third and Eighth Circuits found that employers have no legal obligation under either Fibreboard or Darlington to bargam over partial closings or plant relocations. In $N L R B v$. William J. Burns International Detective Agency, Inc. ${ }^{59}$ the coinpany informed the union, shortly after the union was certified, that the company was discontinuing its guard operations in Oinaha, Nebraska, to avoid financial losses. Similarly, in $N L R B$ v. Royal Plating \& Polishing $C o .{ }^{60}$ the company decided, without bargaining with the union, to sell one of its plants under a threat of condemnation proceeding by a local government agency. And in NLRB v. Adams Dairy, Inc. ${ }^{61}$ the einployer dairy decided, for economic reasons, to sell its products to independent distributors and to stop making deliveries itself. The dairy then fired all einployee drivers engaged in deliveries.

same line of commercial activity as the closed plant, of sufficient substantiality to give promise of their reaping a beuefit from the discouragement of unionization in that business; (2) act to close their plant with the purpose of producing such a result; and (3) occupy a relationship to the other business which makes it realistically foreseeable that its employees will fear that such business will also be closed down if they persist in organizatioual activities, we think that an unfair labor practice has been nuade out.

Id. at 275-76. On remand the Board found that Milliken had the requisite illegal purpose and found an improper effect of stifling union organization in his other busmesses; Milliken had made several speeches in South Carolina decrying unionism in the textile industry and had sent a inen1orandum to his other mills outlining his anti-umion feelings and notmg that those mills would also be closed if the employees organized. Darlington Mfg. Co., 165 N.L.R.B. 1074 (1967), enforced, 397 F.2d 760 (4th Cir. 1968), cert. denied, 393 U.S. 1023 (1969).

58. See, e.g., Morrison Cafeterias Consol., 177 N.L.R.B. 591 (1969), rev'd on other grounds, 431 F.2d 254 (8th Cir. 1970); Motor Repair, Inc., 168 N.L.R.B. 1082 (1968); A.C. Rochat Co., 163 N.L.R.B. 421 (1967). The Board has had difficulty determining violations under Darlington, at least im part because the Supreme Court seemed to reject the application of a balancing test or the "inhereutly destructive" test to determine a violation. See 380 U.S. at 269 n.10. See also NLRB v. Great Dane Trailers, Inc., 388 U.S. 26 (1967); NLRB v. Erie Resistor Corp., 373 U.S. 221 (1963); NLRB v. Truck Drivers Local 449 (Buffalo Linen), 353 U.S. 87 (1957). It is often impossible to prove that an employer in closing one operation intended to affect union relations $m$ another operation. The effect of the injury occurs in the closed enterprise. Often employees in one part of an operation are unaware of the employer's anti-union activities elsewhere. Few employers will, like Roger Milliken, leave a trail of evidence establishing an intention to curtail union organization in other parts of an enterprise by closing a newly-organized unit. For a further discussion of this problem see Oberer, The Scienter Factor in Sections 8(a)(I) and (3) of the Labor Act: Of Balancing, Hostile Motive, Dogs and Tails, 52 CoRNELL L.Q. 491 (1967); Rabin, supra note 27, at 817-18.

59. 346 F.2d 897 (8th Cir. 1965).

60. 350 F.2d 191 (3d Cir. 1965).

61. 350 F.2d 108 (8th Cir. 1965), cert. denied, 382 U.S. 1011 (1966). 
The appellate courts in all three cases relied upon the limiting language in the Fibreboard majority opinion and the rationale of Justice Stewart's concurring opinion to distinguish the Supreme Court's hold$\mathrm{mg} \mathrm{m}$ that case. ${ }^{62}$ In Burns the court noted that, unlike the employer in Fibreboard, the company neither continued to perform nor subcontract out the work. ${ }^{63}$ In Royal Plating the court found that the decision to close one of the plants was a major investment decision resulting in a substantial withdrawal of capital, rather than a inere substitution as in Fibreboard. ${ }^{64}$ And in Adams Dairy the court found that the einployer had made a basic operational change in its capital structure and not simply a subcontracting arrangement. ${ }^{65}$ The courts in all three cases determined that requiring the employer to bargain over the decision would significantly abridge the coinpany's right to manage its business. In effect, the appellate courts found the converse of Fibreboard to be true: whenever there is not a mere substitution of einployees but rather a significant capital investment decision or a basic operational change, the employer has no duty to bargain.

In addition to relying on Justice Stewart's analysis in Fibreboard, the courts reasoned that nothing in the legislative history of the NLRA suggests that partial-closing decisions should be considered mandatory subjects of bargaining. ${ }^{66}$ The courts also superimposed the Darlington motive test ${ }^{67}$ on Justice Stewart's analysis to determme whether an einployer is required to bargain over its decision to partially terminate an

62. See 346 F.2d at 901-02; 350 F.2d at 196; 350 F.2d at 109-11. Most appellate courts have treated Justice Stewart's concurring opinion as the rationale of the majority decision. Although Chief Justice Warren limited the Fibreboard holding to the facts of the case, nowhere did he suggest that different types of management decision, such as partial closings, would be free of all bargaining duties. Rabim, Limitations on Employer Independent Action, 27 VAND. L. REV. 133, 153-54 (1974).

63. 346 F.2d at 901 .

64. 350 F.2d at 196.

65. 350 F.2d at 111 .

66. 350 F.2d at 195; 350 F.2d at 111. See also Davis v. NLRB, 617 F.2d 1264, 1277 (7th Cir. 1980) (Pell, J., dissenting in part); General Motors Corp., 191 N.L.R.B. 951,952 (1971), enforced sub nom. UAW Local 864 v. NLRB, 470 F.2d 422 (D.C. Cir. 1972). The basis for this proposition seems to be Justice Stewart's remark im his Fibreboard concurrence about the concerns of technology and automation replacing employees:

It is possible that in meeting these problems Congress may eventually decide to give organized labor or government a far heavicr hand in controlling what until now have been considered the prerogatives of private business management. That path would mark a sharp departure from the traditional principles of a free enterprise economy. Whether we would follow it is, within constitutional limitations, for Congress to choose. But it is a path which Congress certainly did not ehoose when it enacted the Taft-Hartley Act.

379 U.S. at 225-26 (Stewart, J., concurring).

67. See note 56 supra and accompanying text. 
enterprise. ${ }^{68}$ Because the courts found that the terminations in these cases were for economic, and not anti-union, reasons, they found no obligation to bargain. In short, partial-closing decisions, unlike subcontracting, are at the "core of entrepreneurial control",69 as long as management's reason for such a decision is economic, there is no requireınent of bargaining under section 8(a)(5).

Whereas the appellate courts have viewed the partial-closing decision from the perspective of management, the Board lias looked primarily through the eyes of the employees. In 1966 the Board in Ozark Trailers, Inc. ${ }^{70}$ explicitly rejected the lioldings of Royal Plating and Adams Dairy and found that the failure to bargain over the decision to close one part of the company's operation violates section 8(a)(5) even though the decision was for purely economic reasons. The Board found that Darlington was inapposite because it dealt only with section 8(a)(3) of the Act, and that the holding of Fibreboard controlled the duty-to-bargain issue. ${ }^{71}$ The Board noted that the decision to close, like the decision to subcontract, is often based upon labor-related costs, which are traditional subjects of collective bargaining. Requiring the employer to bargam over the decision to close would not significantly infringe manageinent rights, because section $8(a)(5)$ does not require the einployer to obtain the agreement of the union before closing, but only requires him to negotiate over the issue in good faith until an impasse is reached. ${ }^{72}$ Moreover, according to the Board any infringement of manageinent rights is outweighed by the possible gains of keeping the plant open and retaining jobs. The Board noted that a decision to close has as great an effect on employees wlio lose their jobs as on employers who undertake a major operational change or investinent decision. Requiring an employer to bargain over the decision to terminate part of an operation would, the Board concluded, promote the industrial harmony sought by the NLRA. ${ }^{73}$

The Courts of Appeals for the First, Second, Fourth, Nintli, Tenth, and District of Columbia Circuits joined the Third and Eighth Circuits and rejected the Board's Ozark Trailers decision. ${ }^{74}$ Most of these

68. 346 F.2d at 902; 350 F.2d at $196 ; 350$ F.2d at 112-13.

69. Fibreboard Paper Prods. Corp. v. NLRB, 379 U.S. 203, 223 (1964) (Stewart, J., concurring); UAW Local 864 v. NLRB, 470 F.2d 422, 424 (D.C. Cir. 1972).

70. 161 N.L.R.B. 561 (1966).

71. Id. at $565-67$.

72. Id. at $568-69$.

73. Id. at 567.

74. See NLRB v. Edward M. Rude Carrier Corp., 541 F.2d 277 (4th Cir. 1976) (no opinion published) (termination of portions of a trucking operation); Royal Typewriter Co. v. NLRB, 533 F.2d 1030 (8th Cir. 1976) (closing of one production plant and relocation of work); International 
courts have found that if an employer's decision to close was at the core of entrepreneurial control and based upon economic, rather than antiunion, reasons, the employer may act unilaterally. Some commentators have suggested that this view is based on the economy's need for a free flow of capital unfettered by collective bargaining requirements. ${ }^{75}$

A few appellate courts have offered additional rationales, emphasizing, for example, the confidentiality involved in operational changes. In International Association of Machinists v. Northeast Airlines, Inc. ${ }^{76}$ the union claimed that the employer had failed to meet its duty to bargain when it entered into a merger agreement that caused the termmation of a number of jobs. The Court of Appeals for the First Circuit found that there was no obligation for the company to discuss the decision witl the union, in part because doing so would reveal the company's plans. "[M]erger negotiations," noted the court, "require a secrccy, flexibility and quickness antithetical to collective bargaining."77

Ass'n of Machinists v. Northeast Airlines, Inc., 473 F.2d 549 (1st Cir.), cert. denied, 409 U.S. 845 (1972) (merger between two airlines); UAW Local 864 v. NLRB, 470 F.2d 422 (D.C. Cir. 1972) (sale of company-owned retail outlets to independent dealers); Morrison Cafeterias Consol., v. NLRB, 431 F.2d 254 (8th Cir. 1970) (shutdown of a cafeteria shortly after the union won an election); NLRB v. Drapery Mfg. Co., 425 F.2d 1026 (8th Cir. 1970) (cessation of one enterprise); NLRB v. Dixie Ohio Express Co., 409 F.2d 10 (6th Cir. 1969) (per curiam) (steamliming an operation of loading and unloading merchandise, causing job terminations); NLRB v. Thompson Transp. Co., 406 F.2d 698 (10th Cir. 1969) (one terminal closed after an election victory by the union); NLRB v. Transmarine Navigation Corp., 380 F.2d 933 (9th Cir. 1967) (relocation of operations because of customer demands); NLRB v. Rapid Bindery, Inc., 293 F.2d 170 (2d Cir. 1961) (transfer of a busmess from one plant to another). The Court of Appeals for the Fifth Circuit has accepted the Board's position in Ozark Trailers. NLRB v. Winn-Dixie Stores, 361 F.2d 512 (5th Cir.), cert. denied, 385 U.S. 935 (1966); NLRB v. American Mfg. Co., 351 F.2d 74 (5th Cir. 1965). The position of the Court of Appeals for the Seventh Circuit is uncertain: the court enforced the Board's decision in Summit Tooling Co., 195 N.L.R.B. 479 (1972), enforced, 474 F.2d 1352 (7th Cir. 1973) (uo opinion published), in which the Board found no duty to bargam over an employer's decision to close its tool manufacturing plant, because the effect of the decision was to take the employer out of the tooling business. See notes 107-10 infra and accompanying text. In the recent case of Davis v. NLRB, 617 F.2d 1264 (7th Cir. 1980), however, the court in a 2-1 panel decision upheld a Board finding that an employer had a duty to negotiate over its determmation to change from a full service restaurant to a cafeteria, which change caused a number of employees to lose their jobs. Recently the Courts of Appeals for the Second, Third, and Sixth Circuits have also retreated from their earlier positions adverse to Ozark Trailers. See notes 120-24 infra and accompanying text.

75. See, e.g., Comment, "Partial Terminations"-A Choice Between Bargaining Equality and Economic Efficiency, 14 U.C.L.A. L. Rev. 1089, 1091 (1967). See also Brockway Motor Trucks v. NLRB, 582 F.2d 720, $748-49$ (3d Cir. 1978) (Rosenn, J., dissenting), on remand, 251 N.L.R.B. No. 23, 104 L.R.R.M. 1515 (1980); Farmer, Bargaining Requirements in Connection with Subcontracting, Plant Removal, Sale of Business, Merger and Consolidation, 14 LAB. L.J. 957, 960 (1963).

76. 473 F.2d 549 (1st Cir.), cert. denied, 409 U.S. 845 (1972). See also Geueral Motors Corp. 191 N.L.R.B. 951 (1971), enforced sub nom. UAW Local 864 v. NLRB, 470 F.2d 422 (D.C. Cir. 1972).

77. 473 F.2d at 557. See also 191 N.L.R.B. at 952. 
Other courts have stated that providing notice prior to closing a plant could be detrimental to employee morale, productivity, and discipline because employees would have hittle incentive to continue to perform their duties. ${ }^{78}$ As key employees left and production deteriorated, a plant might have to be closed even sooner than planned. Additionally, the premature disclosure of an employer's poor financial condition, a typical cause of a company's decision to close, could threaten business relations with customers and suppliers. ${ }^{79}$ In sliort, a requirement of prior notice when an employer is considering closing could itself damage the business and thus be contrary to the employees' best interests.

Courts also have reasoned that in many situations any negotiation with einployees over a partial shutdown would be futile. ${ }^{80}$ The most common reason for business terminations is the losses suffered by the employer, many of which are caused by forces outside the control of either the company or the union. Not only would bargaining in such cases be fruitless, but also the employees and the union would have no incentive to agree to the closing. The union's best strategy might be to prolong negotiations to forestall the closing and keep the workers einployed for the longest possible tinne regardless of the econonic consequences to the company. To require an einployer to bargain in such circumstances would aggravate the company's financial problems. Finally, courts have pointed out that such bargaining is senseless because employees or their representatives have hittle familiarity with the complex financial considerations which must go into a liquidation, merger, or partial closing. ${ }^{81}$

Two unstated concerns seem to underlie appellate court decisions that hold an employer should have no duty to bargain over a determination to close a plant. One is the problein of deciding when the duty to bargain arises and for how long it continues. ${ }^{82}$ The other is the problem of choosing an appropriate remedy if an einployer violates this

78. See, e.g., Brockway Motor Trucks v. NLRB, 582 F.2d 720, 749 (3d Cir. 1978) (Rosenn, J., dissenting), on remand, 251 N.L.R.B. No. 23, 104 L.R.R.M. 1515 (1980). See also Rabin, supra note 62 , at 155 .

79. 582 F.2d at 748 (Rosenn, J., dissenting).

80. See UAW Local 864 v. NLRB, 470 F.2d 422 (D.C. Cir. 1972). See also O'Connell, The Implications of Decision Bargaining, 16TH ANN. N.Y.U. CONF. ON LABOR LAW 99 (1963).

81. Interuational Ass'n of Machinists v. Northeast Airlines, Inc., 473 F.2d 549, 557 (1st Cir.), cert. denied, 409 U.S. 845 (1972). See also General Motors Corp., 191 N.L.R.B. 951,952 (1971), enforced sub nom. UAW Local 864 v. NLRB, 470 F.2d 422 (D.C. Cir. 1972); Goetz, supra note 27, at 10; Schwar, supra note 27 , at $95-96$.

82. See, e.g. , Brockway Motor Trucks v. NLRB, 582 F.2d 720, 748 (3d Cir. 1978) (Rosenn, J., dissenting), on remand, 251 N.L.R.B. No. 23, 104 L.R.R.M. 1515 (1980). 
bargaining obligation. ${ }^{83}$ The Board lias held that an employer must notify and negotiate with the union concerning a partial closing at a time when such bargaining could have some effect on management's decision. The Board has described this time as "the poimt of [management's] thinking seriously about" a closing, ${ }^{84}$ or when there is still occasion for "meaningful discussion of the decision." 85 This vague language could mean that a company must bargain when management first considers a possible closing, or when it undertakes a study of the feasibility of continuing a plant in operation, or just prior to a formal approval of the termination. The Board's own inconsistencies liave compounded the problems of proper timing. In Royal Plating \& Polishing Co. ${ }^{86}$ and in Royal Typewriter Co. ${ }^{87}$ for example, the Board found that each company's notification to the involved union of the possible termination approximately one week before the final closing was inadequate. Yet in Farm Crest Bakeries ${ }^{88}$ notice and bargaining two days before the decision to close was found sufficient, and in General Motors Corp. ${ }^{89}$ notice to the employees after the sale of part of an enterprise was held to be proper.

Additionally, if financial difficulties impel a decision to close an operation, management may be reluctant to make any concessions to a union's almost certam request for a delay or reversal of the decision, especially if a speedy closing is important. In negotiations where management refuses to budge froin its position, the Board may be tempted to find that the company did not meet its bargaining obligations under the NLRA, but ratlier engaged only in "surface bargaining."

83. See, e.g., NLRB v. Adams Dairy, Inc., 350 F.2d 108, 115 (8th Cir. 1965), cert. denied, 382 U.S. 1011 (1966).

84. See Ozark Trailers, Inc., 161 N.L.R.B. 561,569 (1966).

85. See Royal Typewriter Co., 209 N.L.R.B. 1006, 1013 (1974), enforced, 533 F.2d 1030 (8th Cir. 1976).

86. 148 N.L.R.B. 545, 555 (1964), enforcement denied, 350 F.2d 191 (3d Cir. 1965). The company on June 14, 1963, gave notice to the union of the sale of one of its plants to a government housing authority. By the end of June the company had fired all its employees, and on July 10 it sold its machinery and equipment at public auction.

87. 209 N.L.R.B. 1006, 1012-13 (1974), enforced, 533 F.2d 1030 (8th Cir. 1976). On April 15, 1969, the company informed the union that it was considering permanently closing the plant; bargaining began on that date. On April 23 the company announced its decision to close the plant and move production work to another location.

88. 241 N.L.R.B. No. 195, 101 L.R.R.M. 1071 (1979).

89. 191 N.L.R.B. $951,958-59$ (1971). The company agreed to sell a trucking retail outlet to an imdependent dealer on June 6, 1969. On June 9 it informed the einployees of this sale and of the termination of their jobs.

90. For definitions of "surface bargaining" see NLRB v. Reed \& Prince Mfg. Co., 205 F.2d 131 (1st Cir.), cert. denied, 346 U.S. 887 (1953); R. GORMAN, LABOR LAW 481-82 (1976). While the Board cannot compel parties to agree, H.K. Porter Co. v. NLRB, 397 U.S. 99 (1970), the Board can compel parties to bargain in good faith. 29 U.S.C. \& 158(d) (1976). Surface bargaining occurs 
A finding of a refusal to bargain can have dire effects on a coinpany. When the Board finds a violation of the duty to bargain, it typically orders bargaining over a resumption of the closed business, coupled with some form of back pay award.91 The Board has also, in some cases, required an employer to place discharged workers on preferential hiring hists at other plants and to pay those workers' relocation costs. ${ }^{92}$ In a few instances the Board has even ordered the employer to resume the discontinued operation, ${ }^{93}$ as the Suprene Court did in Fibreboard. These remedies can be extremely costly for a business that had initially been closed because of economic difficulties. In addition to the immediate losses such remedies may impose on an employer, the

when a party goes through the motions of negotiations without a good faith desire to reach an agreement. To determine whether parties are involved in true negotiations or are engaged in mere surface bargaining, the Board applies a "totality of circumstances" test. The Board will look at such factors as the proposals, counter-proposals, and concessions made by parties to determine their subjective states of mind; their statements and conduct at the bargaining table; the length of the negotiations; the failure to designate a bargaining agent with sufficient authority; dilatory tactics with an inherent intent to reach impasse, or arbitrary scheduling of the day and time of bargaining ineetings. See Continental Ins. Co. v. NLRB, 495 F.2d 44 (2d Cir. 1974); Firch Baking Co. v. NLRB, 479 F.2d 732 (2d Cir.), cert. denied, 414 U.S. 1032 (1973).

91. The purpose of the remedy is to recreate the type of strength that the union would have had if the company had imitially met its obligation to bargain:

[A] bargaining order, alone, cannot serve as an adequate remedy for the unfair labor practices committed. The Act requires inore than pro forma bargaining, but pro forma bargaining is all that is likely to result unless the Union can now bargain under conditions essentially similar to those that would have obtained had Respondents bargained in good faith at the time the Act required them to do so. If the union must bargain devoid of all economic strength, we would perpetuate the situation created by Respondents' unlawful conduct which precluded meaningful bargaining.

Royal Typewriter Co., 209 N.L.R.B. 1006, 1015 (1974) (footnote omitted), enforced, 533 F.2d 1030 (8th Cir. 1976). See also NLRB v. Production Molded Plastics, Inc., 604 F.2d 451 (6th Cir. 1979); First Nat'l Maintenance Corp., 242 N.L.R.B. No. 72, 101 L.R.R.M. 1177 (1979), enforced, 627 F.2d 596 (2d Cir. 1980), cert. granted, 49 U.S.L.W. 3480 (U.S. Jan. 13, 1981) (No. 80-544); Midland-Ross Corp., 239 N.L.R.B. 323 (1978), enforced, 617 F.2d 977 (3d Cir.), cert. denied, 101 S. Ct. 210 (1980).

92. First Nat'l Maintenance Corp., 242 N.L.R.B. No. 72, 101 L.R.R.M. 1177 (1979), enforced, 627 F.2d 596 (2d Cir. 1980) (preferential hiring at other facilities if operations are not resumed), cert. granted, 49 U.S.L.W. 3480 (U.S. Jan. 13, 1981) (No. 80-544); Midland-Ross Corp., 239 N.L.R.B. 323 (1978), enforced, 617 F.2d 977 (3d Cir. 1980) (establish a preferential hiring list and offer to pay relocation expenses to other facilities if the plant is not reopened), cert. denied, $101 \mathrm{~S}$. Ct. 210 (1980); Royal Typewriter Co., 209 N.L.R.B. 1006 (1974), enforced, 533 F.2d 1030 (8th Cir. 1976) (if the plant is not reopened, establish a preferential hiring list at another facility that engages in similar operations as the closed plant and offer to pay moving and transportation costs). But of. NLRB v. W.R. Grace \& Co., 571 F.2d 279 (5th Cir. 1978) (holding that the Board's remedy of requiring reinstatement if the employer reopens the facility, or of establishing a preferential hiring list, is improper).

93. Smith Mfg. Co., 247 N.L.R.B. No. 164, 103 L.R.R.M. 1432 (1980); Soule Glass \& Glazing Co., 246 N.L.R.B. No. 135, 102 L.R.R.M. 1693 (1979); Case, Inc., 237 N.L.R.B. 798 (1978). The Board is hesitant, lowever, to use this approach. See, e.g., Capitol Chrysler-Plymouth, 242 N.L.R.B. No. 178, 101 L.R.R.M. 1374 (1979); Co-Ed Garment Co., 231 N.L.R.B. 848 (1978); P.B. Mutrie Motor Transp., Inc., 226 N.L.R.B. 1325 (1976); Walter Pape, Inc., 205 N.L.R.B. 719 (1973). 
employer may also be forced to forego "opportunities to liquidate assets, sell or lease properties, or disengage from burdensome contracts."94 The harsh effects of these remedies have undoubtedly made courts hesitant to find that a violation of the duty to bargam occurred in a closimg situation..$^{95}$

Although the NLRB's basic policy that an employer must bargaim over partial closings has remaimed the same, ${ }^{96}$ the Board has begun to find exceptions to its per se approach. This retreat has undoubtedly been influenced by appellate court reversals of Board decisions. ${ }^{97}$ In 1971 the Board, in General Motors Corp. ${ }^{98}$ aligned itself with the courts by refusing to require an employer to bargam over its decision to sell a retail outlet to an independent dealer, even though the sale resulted in all of the prior employees' losing their jobs. What made the Board's new stance even more surprising were the facts of the case: the union, upon hearing rumors of a possible sale, had requested the company to bargain prior to any decision to sell, but the company flatly refused.99 The Board majority first noted the nuinber of court decisions that had rejected its approach in partial-closing cases. ${ }^{100}$ Without citing Ozark Trailers, the Board then held that because the decision to sell the enterprise was a matter "essentially financial and managerial im nature . . . [lymg] at the very core of entrepreneurial control," and because the decision would "require secreey as well as the freedom to act quickly and decisively," there was no legal obligation for the employer to bargam. ${ }^{101}$

Three years later in Royal Typewriter ${ }^{102}$ the Board returned to its

94. Brockway Motor Trucks v. NLRB, 582 F.2d 720, 749 (3d Cir. 1978) (Rosenn, J., dissenting), on remand, 251 N.L.R.B. No. 23, 104 L.R.R.M. 1515 (1980).

95. See, e.g., NLRB v. Adams Dairy, Inc., 350 F.2d 108, 115 (8th Cir. 1965), cert. denied, 382 U.S. 1011 (1966).

96. See, e.g., ABC Trans-Nat'l Transp. Inc., 247 N.L.R.B. No. 25, 103 L.R.R.M. 1116 (1980); National Family Opinion, Inc., 246 N.L.R.B. No. 84, 102 L.R.R.M. 1641 (1979); Blake Constr. Co., 245 N.L.R.B. No. 76, 102 L.R.R.M. 1471 (1979); Caltrans Systeuns, Inc., 245 N.L.R.B. No. 90, 102 L.R.R.M. 1417 (1979). See also Davis v. NLRB, 617 F.2d 1264, 1268 (7th Cir. 1980); Brockway Motor Trucks v. NLRB, 582 F.2d 720, 731 (3d Cir. 1978), on remand, 251 N.L.R.B. No. 23, 104 L.R.R.M. 1515 (1980).

97. In General Motors Corp., 191 N.L.R.B. 951 (1971), enforced sub nom. UAW Local 864 v. NLRB, 470 F.2d 422 (D.C. Cir. 1972), the in ajority opinion acknowledged that "the courts have sustained the Board's position in subcontracting cases, but rejected Board decisions requiring bargaining over inore eleinental inanageinent decisions, such as plant closings and plant removals." 191 N.L.R.B. at 951 (footnotes ounitted).

98. 191 N.L.R.B. 951 (1971), enforced sub nom. UAW Local 864 v. NLRB 470 F.2d 422 (D.C. Cir. 1972).

99. 191 N.L.R.B. at 957-58.

100. See note 97 supra.

101. 191 N.L.R.B. at 952.

102. 209 N.L.R.B. 1006 (1974), enforced, 533 F.2d 1030 (8th Cir. 1976). 
original position in Ozark Trailers. The Board distinguished General Motors on the grounds that it involved an economic decision to sell an independent dealership, ${ }^{103}$ whereas in Royal Typewriter the company had decided to close one of its plants but to continue inanufacturing similar products at another facility in the United States. The Board found that this partial shutdown and relocation of operations was a mandatory subject of bargaining. ${ }^{104}$ The two cases are difficult to reconcile: the effect on the employees in both situations was a loss of jobs; bargaining might have convinced either employer to remain in business; and both cases involved substantial financial reallocations.

Recently the Board again retreated from Ozark Trailers. In Brockway Motor Trucks ${ }^{105}$ a company decided, for economic reasons, to close one of its plants that manufactured, sold, and serviced trucks. The Board restated its basic position that in partial-closing cases an employer's decision to close, made without bargaining, violates section 8(a)(5). The Board noted, however, that the company had not shown that its decision involved such a "significant investınent or withdrawal of capital" that it "affect[ed] the scope and ultimate direction of the enterprise."106 This reference could signal that the Board believes that partial-closing decisions based upon substantial economic considerations be in the sole discretion of inanagement.

The Board has found a number of other reasons not to require bargaining in various situations. When a company has terminated a distimct line of its business, the Board has not compelled negotiations

103. 209 N.L.R.B. at 1012.

104. Id.

105. 230 N.L.R.B. 1002 (1977), enforcement denied without prejudice to commencement of additional proceedings, 582 F.2d 720 (3d Cir. 1978), on remand, 251 N.L.R.B. No. 23, 104 L.R.R.M. 1515 (1980).

106. 230 N.L.R.B. at 1003. The Board intimated that if the closing had called for a major financial reinvestment or for a change in the coinpany's operation as a whole, there might have been no duty to bargain. See Brockway Motor Trucks v. NLRB, 582 F.2d 720, 724 n.7 (3d Cir. 1978), on remand, 251 N.L.R.B. No. 23, 104 L.R.R.M. 1515 (1980). Such a holding would be a retreat to the rationale of General Motors; see notes 98-101 supra and accompanying text. In Brockway the company had set a new policy to eliminate company-owned truck dealerships like the Philadelphia dealership at issue in the case. This particular dealership had lost inore inoney than any other before its closing; after that closing the company liquidated all of its truck dealerships and manufacturing operations. See Brockway Motor Trucks, 251 N.L.R.B. No. 23, 104 L.R.R.M. 1515 (1980). The facts of the case are thus almost identical to those of General Motors: the employer in that case similarly dispesed of a company-owned truck dealership in furtherance of a general corporate policy to sell such branches to independent dealer-owners. The liquidation in Brockway Motors could hardly have been any less of a "withdrawal of capital" or have less "affect[ed] the scope and ultimate direction of the enterprise" than in General Motors. See id., 104 L.R.R.M. at 1518. 
even though the company has continued other operations. ${ }^{107}$ In Kingwood Mining Company, ${ }^{108}$ for example, the employer shut down and subcontracted out its coal-mining operations but continued to process and sell coal. The Board found that mining was independent of processing and selling and that by shutting down the coal mine, the einployer had left the mining business entirely. Noting that manageinent's decision involved a substantial withdrawal of capital, the Board found that a bargaming obligation would "significantly abridge [the employer's] freedoin to inanage its own affairs." 109 These facts differ only slightly froin those in Ozark Trailers and Royal Typewriter. In Kingwood Mining the coinpany did not coinpletely eliminate itself as an employer; the operations reinaining were similar to those terminated. Moreover, the decision to withdraw capital by discontinuing a discrete line of business substantially parallels the decisions inade in Ozark Trailers and Royal Typewriter to withdraw capital by closing a plant and discontinuing production. ${ }^{110}$

The Board has also deferred to manageinent when it has found a need for immediate action or a lack of any alternative to a closing. ${ }^{111}$ In Brooks-Scanlon, Inc., ${ }^{112}$ for exainple, the company informed the union that it had decided to close one of its sawmill operations because of an insufficient supply of local timber. A inajority of the Board found

107. See Gray-Grimes Tool Co., 221 N.L.R.B. 736 (1974) (an automotive distributor closed its parts manufacturing operation), modified on other grounds, 557 F.2d 1233 (6th cir. 1977); Stanley Oil Co., 213 N.L.R.B. 219 (1974) (an employer closed its service department); Kingwood Minmg Co., 210 N.L.R.B. 844 (1974), affd sub nom. UMW v. NLRB 515 F.2d 1018 (D.C. Cir. 1975) (a company ceased its coal mining but continued to process and sell coal); Summit Tooling Co., 195 N.L.R.B. 479 (1972), enforced, 474 F.2d 1352 (7th Cir. 1973) (a company ceased its manufacturing of tool and die equipment).

108. 210 N.L.R.B. 844 (1974), affd sub nom. UMW v. NLRB, 515 F.2d 1018 (D.C. Cir. 1975).

109. 210 N.L.R.B. at 845 .

110. See notes 102-04 supra and accompanying text. See also 92 HARV. L. Rev. 768, 773-74 (1979).

111. See Brooks-Scanlon, Inc., 246 N.L.R.B. No. 76, 102 L.R.R.M. 1606 (1979) (the loss of a sufficient quantity of natural resource-pine timber-to contimue busimess); Raskin Packing Co., 246 N.L.R.B. No. 15, 102 L.R.R.M. 1489 (1979) (a bank unexpectedly withdrew its line of credit and within hours the company decided to close); Key Coal Co., 240 N.L.R.B. No. 153, 100 L.R.R.M. 1444 (1979) (an employer ceased its operation because of a lawsuit); M \& M Transp. Co., 239 N.L.R.B. 73 (1978) (a company terminated immediately upon learning it lacked funds to continue operating or to meet its payroll); National Terminal Baking Corp., 190 N.L.R.B. 465 (1971) (the theft of a second truck caused an employer to end its business). See also Kroehler Mfg. Co., NLRB General Counsel Advice Memo \#9-CA 9787, reprinted in 93 L.R.R.M. 1252 (1976) (an employer decided to relocate its plant rather than rebuild it after the structure was destroyed by a tornado). In NLRB v. Production Molded Plastics, Inc., 604 F.2d 451 (6th Cir. 1979), the court held that the employer's fear that his natural gas supply would be curtailed was an insufficient excuse for failing to bargain over the transfer of plant machinery and 15 jobs to a Canadian facility.

112. 246 N.L.R.B. No. 76, 102 L.R.R.M. 1606 (1979). 
that bargaining would be futile because nothing could increase the supply of a limited natural resource, and it thus held that the unilateral decision to close was lawful. ${ }^{113}$ But the short supply of timber did not preclude alternatives that the union might have proposed in order to keep the plant open. ${ }^{114}$ It had previously been the possibility of alternatives, rather than the probability of successful agreenient, that was the Board's test of the employer's bargaining obligation in partial-closing cases. ${ }^{115}$

Finally, im many instances the Board has found that a union waives its right to bargam over a partial closing either by agreeing to express contractual language reserving to management the right to close an operation, or by failing to request bargaining after notice of manageinent's intentions to close. ${ }^{116}$ In the case of International Offset Corp. 117 the employer failed to notify or bargain with two unions before closing its printing operations. The Board ruled that the unions knew or should have known that a shutdown was imminent in light of the company's successive sales and transfers of machinery, the nunber of layoffs, the newspaper advertisements concerning the possible sale of assets by the coinpany, and conversations with a conipany official. According to the Board, the union's failure to request bargaining despite this knowledge precluded the finding of an 8(a)(5) violation. ${ }^{118}$ In unany similar cases, however, the union knew of the company's poor economic position or of the company's intention to close before the actual decision was inade, but the Board found no waiver of the union's bargaining rights. ${ }^{11}$ To say the least, unions will have diffculty predicting what knowledge the Board will consider sufficient to

113. $I d$.

114. Id., 102 L.R.R.M. at 1608 (Murphy, M., dissenting).

115. $I d$.

116. ABC Transnat'1 Transp., Inc., 244 N.L.R.B. No. 109, 102 L.R.R.M. 1357 (1979); Key Coal Co., 240 N.L.R.B. No. 153, 100 L.R.R.M. 1444 (1979); American Can Co., 218 N.L.R.B. 102 (1975), enforced, 535 F.2d 180 (2d Cir. 1976); Vegas Vic, Inc., 213 N.L.R.B. 841 (1974), enforced, 546 F.2d 828 (9th Cir. 1976), cert. denied, 434 U.S. 818 (1977); Stanley Oil Co., 213 N.L.R.B. 219 (1974); International Offset Corp., 210 N.L.R.B. 854 (1974); Manitowoc Co., 186 N.L.R.B. 994 (1970); New Era Shirt Co., 181 N.L.R.B. 975 (1970); United States Lingerie Corp., 170 N.L.R.B. 750 (1968); White Consol. Indus., 154 N.L.R.B. 1593 (1965); Shell Oil Co., 149 N.L.R.B. 305 (1964); Montgomery Ward \& Co., 137 N.L.R.B. 418 (1962). See also NLRB v. Spun-Jee Corp., 385 F.2d 379 (2d Cir. 1967); Schwarz, supra note 27, at 92-94.

117. 210 N.L.R.B. 854 (1974).

118. Id. at 855 .

119. See, e.g., First Nat'1 Maintenance Corp., 242 N.L.R.B. No. 72, 101 L.R.R.M. 1177 (1979), affd, 627 F.2d 596 (2d Cir. 1980), cert. granted, 49 U.S.L.W. 3480 (U.S. Jan. 13, 1981) (No. 80544); Case, Inc., 237 N.L.R.B. 798 (1978). See also Davis v. NLRB, 617 F.2d 1264, 1277-78 (7th Cir. 1980) (Pell, J., concurring in part and dissenting in part), in which Judge Pell noted the difference between the Board's holding is in cases such as International Offset Corp. and its holdings in other partial-closing cases. 
shift the burden of requesting bargaining to the union, particularly because the union cannot be aware of exactly when the company will actually cease operations.

As the Board has retreated from its Ozark Trailers approach, some courts have inoved closer to requiring collective bargaining in partial closings. ${ }^{120}$ In Brockway Motor Trucks $v . N L R B^{121}$ the Court of Appeals for the Third Circuit modified the position it took in $N L R B v$. Royal Plating \& Polishing, Inc., ${ }^{122}$ and found that an employer is not relieved of its duty to bargam under section $8(\mathrm{a})(5)$ nierely because the partial closing results from unspecified "economic conditions." 123 Rather, stated the court, the countervailing interests of the einployers and employees inust be balanced in determining the duty to bargam. 124 Because the employer in Brockway had failed to denionstrate that economic factors compelled it to close without bargaining with the union, the court found that the employer had violated the Act. Whether this opinion reflects a change in the approach that the courts of appeals will take in partial-closing or renoval cases remains to be seen. These recent cases demonstrate, however, that the Board and the courts have been moving in opposite directions, undoubtedly perplexing companies, unions, and employees.

120. See NLRB v. First Nat'1 Maintenance Corp., 627 F.2d 596 (2d Cir. 1980) (2-1 decision), cert. granted, 49 U.S.L.W. 3480 (U.S. Jan. 13, 1981) (No. 80-544); Davis v. NLRB, 617 F.2d 1264 (7th Cir. 1980) (2-1 decision); Midland-Ross Corp. v. NLRB, 617 F.2d 977 (3d Cir.) (2-1 dccision), cert. denied, 101 S. Ct. 210 (1980); NLRB v. Production Molded Plastics, Inc., 604 F.2d 451 (6th Cir. 1979) (3-0 decision); Brockway Motor Trucks v. NLRB, 582 F.2d 720 (3d Cir. 1978) (2-1 decision), on remand, 251 N.L.R.B. No. 23, 104 L.R.R.M. 1515 (1980).

In Davis $v . N L R B$ the employer changed its restaurant from a full-service dining facihty to a self-service cafeteria. The Court of Appeals for the Seventh Circuit cited Ozark Trailers and Brockway Motor Trucks with approval, 617 F.2d at 1268, but also noted that "[t]his is not the case where an employer has exercised his managerial prerogative to terminate, relocate, liquidate or sell his business or a part of it." Id. The Court also found that the change in operation did not involve major capital reinvestment; the holding therefore does not apply to a traditional partial closing, in which a company decides to alter a significant portion of its operation.

Likewise, in NLRB v. Production Molded Plastics, Inc, the Court of Appeals for the Sixth Circuit found that there was less than a partial closing:

In fact, they have neither sold nor abandoned, nor completely closed the "small plant" at Alliance, Ohio. The transfer of some machinery and 15 jobs to their Canadian plant did not involve any major commitment of capital to a new enterprise nor any withdrawal from a previous line of company endeavor. Indeed, the same work continued to be performed on the saine machinery in the Canadian plant, albeit by other employees.

604 F.2d at 453. Thus, one cannot say with certainty that the Seventh and Sixth Circuits would extend their recent holdings to an employer's substantial termination of operations.

121. 582 F.2d 720 (3d Cir. 1978), on remand, 251 N.L.R.B. No. 23, 104 L.R.R.M. 1515 (1980).

122. 350 F.2d 191 (3d Cir. 1965). See text accompanying notes $60 \& 62$ supra.

123. 582 F.2d at 739.

124. Id. at $737-40$. 


\section{CRItique}

\section{A. The Deficiencies of the Board's Approach.}

The NLRB has shown too little deference to the needs of management when a company decides to close or relocate a plant. Although labor-related costs can be a major factor in such decisions, there is usually a plethora of other considerations. A closing or relocation can result from the demands or the loss of a customer, ${ }^{125}$ outdated machinery or a need for expansion, ${ }^{126}$ the elimination of reliable sources of production materials, ${ }^{127}$ or factors such as increased overhead expenses, more dependable transportation, or a more advantageous marketing position. ${ }^{128}$

Before closing a plant, most corporations undoubtedly analyze the costs and benefits. ${ }^{129}$ Often such studies require hiring consultants, meetmg with investment and legal advisers, and discussing the proposed closing with the board of directors. An ill-advised plant closing or relocation can have disastrous effects on an entire business. ${ }^{130}$ Moreover, a partial liquidation frequently demands a speed and timing that are absent from the typical collective bargaining situation. ${ }^{131}$ In such cases the Board should not judge the adequacy of the negotiations that take place between an employer and a union by the same standards it uses in determining whether an employer has engaged in "surface bargaining" in a labor contract negotiation. ${ }^{132}$ The issues mvolved in bargaining over the decision to close a plant will be relatively few in comparison to the typical labor contract negotiation. ${ }^{133}$ Moreover, the

125. See, e.g., NLRB v. Thompson Transp. Co., 406 F.2d 698 (10th Cir. 1969); NLRB v. Transmarine Navigation Corp., 380 F.2d 933 (9th Cir. 1967).

126. See, e.g., United Steelworkers Local 1330 v. United States Steel Corp., 492 F. Supp. 1 (N.D. Ohio), aff'd in part and rev'd in part, 631 F.2d 1264 (6th Cir. 1980).

127. See, e.g., Brooks-Scanlon, Inc., 246 N.L.R.B. No. 76, 102 L.R.R.M. 1606 (1979).

128. Rubinstem, Plant Relocation and Its Effects on Labor Management Relations, 18 LAB. L.J. 544, 550-51 (1967); Swift, supra note 27, at 1137. For an interestimg discussion of the many causes which led to the closing of an automotive assenibly plant, see Corley, Closing of a Ford Plant Reflects Rising Worry of Car Makers: Quality, Wall St. J., June 16, 1980, at 1, col. 6.

129. See, e.g., Fibreboard Paper Prods. Corp. v. NLRB, 379 U.S. 203, 206 (1964); MidlandRoss Corp. v. NLRB, 617 F.2d 977, 979-80, 982-83 (3d Cir.), cert. denied, 101 S. Ct. 210 (1980); NLRB v. Winn-Dixie Stores, 361 F.2d 512 (5th Cir.), cert. denied, 385 U.S. 935 (1966). See also Swift, supra note 27 , at 1138 .

130. Swift, supra note 27, at 1138.

131. See, e.g., Raskin Packing Co., 246 N.L.R.B. No. 15, 102 L.R.R.M. 1489 (1979); M \& M Transp. Co., 239 N.L.R.B. 73 (1978); National Terminal Baking Corp., 190 N.L.R.B. 465 (1971). See also Kroeller Mfg. Co., NLRB General Counsel Advice Meino \#9-CA 9787, reprinted in 93 L.R.R.M. 1252 (1976).

132. See note 90 supra.

133. Certainly the union will attempt to convince the employer not to close or transfer an operation. The union may also want to negotiate the manner, timing, and implenentation of the 
union and the company will generally have opposite interests. When the decision to close is supported by considerations outside the einployment relationship, such as the exhaustion of essential production material or the loss of a necessary line of credit, the company may have neither the time nor the ability to agree to union deinands. For the Board to require bargaining over alınost all plant closing decisions, and to apply its usual standards of good faith to such bargaining, will discourage rather than encourage bargaining. ${ }^{134}$ Most employers will seek to evade bargaining and few courts reviewing a Board order will find that the employer had a duty to bargain.

Perhaps the major failure of the Board's bargaining requireinent is its imsensitivity to the claim of employers that they cannot inform unions about a proposed partial closing for reasons of confidentiality. Even the Supreme Court has noted that it is difficult to pledge union representatives to the nondisclosure of sensitive information. ${ }^{135}$ This is particularly true when the negotiations concern the jobs of all employees in the bargaining unit. As some courts have suggested, untimely leaks might have adverse consequences not only on einployee inorale and relations with customers and suppliers, ${ }^{136}$ but also with respect to potential purchasers of the plant.

In addition, corporate officers risk liability under federal securities laws if they reveal material information to a union before a final deci-

decision. See, e.g., Davis v. NLRB, 617 F.2d 1264, 1270 (7th Cir. 1980). Finally, the union may want to discuss the possible pnrchase of the business. See, e.g., United Steekworkers Local $1330 \mathrm{v}$. United States Steel Corp., 492 F. Supp. 1 (N.D. Ohio 1980), aff'd in part and rev'd in part, 631 F.2d 1264 (6th Cir. 1980).

134. For cases in which the Board has determined that an employer bargained with the union over the decision to close a portion of a business bnt that the negotiations failed to satisfy section 8(a)(5), see ABC Trans-Nat'1 Tranp., Inc., 247 N.L.R.B. No. 25, 103 L.R.R.M. 1116 (1980); Ohio Brake \& Clutch Corp., 244 N.L.R.B. No. 4, 101 L.R.R.M. 1601 (1979); First Nat'l Maintenance Corp., 242 Nं.L.R.B. No. 72, 101 L.R.R.M. 1177 (1979), affd, 627 F.2d 596 (2d Cir. 1980), cert. granted, 49 U.S.L.W. 3480 (U.S. Jan. 13, 1981) (No. 80-544); Case, Inc., 237 N.L.R.B. 798 (1978); Royal Typewriter Co., 209 N.L.R.B. 1006 (1974), enforced, 533 F.2d 1030 (8th Cir. 1976); Walter Pape, Inc., 205 N.L.R.B. 719 (1973).

135. In Detroit Edison Co. v. NLRB, 440 U.S. 301 (1979), a union had filed unfair labor practice charges against an employer under section 8(a)(5) for the company's refusal to give the union copies of tests used to determine promotions, and the answer sheets, which the union allegcd it needed to process grievances. Both the Board and the Court of Appeals for the Sixth Circuit ordered the company to produce the tests and answer sheets, while ordering the union not to disclose these to any employees who might take the test. See Detroit Edison Co., 218 N.L.R.B. 1024 (1975), affd, 560 F.2d 722 (6th Cir. 1977), vacated and remanded, 440 U.S. 301 (1979). The Supreme Court held that such a confidentiality requirement could not be enforced since the union was not a party to the proceeding under section 10(e) of the NLRA. 440 U.S. at 315-16. The Court further noted that even if the union were considered a party and subject to contempt proceedings for violating the Court's order, any remedy available to the Court was inadequate because it could not protect against the "danger of inadvertent leaks." 440 U.S. at 316.

136. See note 78 supra. 
sion on a plant termination. If a union prematurely discloses information received from the employer that turns out to be imcorrect, persons who have bought or sold securities in reliance on the information miglit sue both the company and management officials. ${ }^{137}$ Defending suits brought under section 10(b) of the Securities and Exchange Act ${ }^{138}$ or other antifraud securities laws could prove costly.

If the Board continues to require employers to bargain over partial-closing decisions, it must devise means to protect legitimate management concerns. The Board lias not yet fashioned sanctions for a union's disclosure of nonpublic inside information; nor las it considered penalizing a union that unduly delays bargaining when, from the employer's point of view, time is of the essence. Indeed, in partial closings the union has little incentive to conclude negotiations. The longer that the union prolongs bargaining over the decision to close, by requiring information or discussing tangential matters, the longer its members remain employed.

The Board should also resolve the uncertainties concerning when the duty to bargam arises im plant termination cases. Although it is

137. See Securities Exchange Act of 1934,15 U.S.C. $\$ \$ 78 \mathrm{i}, 78 \mathrm{j}$ (b), 78t (1976); rule 10b-5, 17 C.F.R. $\$ 240.10 \mathrm{~b}-5$ (1980). The closing of part of a business would certainly be a "inaterial fact" as it would be one 'which in reasonable and objective contemplation might affect the value of the corporation's stock or securities . . . " Kohler v. Kohler Co., 319 F.2d 634, 642 (7th Cir. 1968), quoted in SEC v. Texas Gulf Sulphur Co., 401 F.2d 833, 849 (2d Cir. 1968), cert. denied, 404 U.S. 1005 (1971). If a corporate official improperly conceals or misrepresents a material fact, causing a security transaction, he may be hable under the federal securities laws. See, e.g., SEC v. United Fin. Group, Inc., 474 F.2d 354, 358 n.9 (9th Cir. 1973) (concealment of the insolvency of affiliates); Hohmann v. Packard Instrument Co., 471 F.2d 815, 820 (7th Cir. 1973) (failure to disclose intent to stop production of a significant product); Gladwin v. Medfield Corp., [1974-1975 Transfer Binder] FED. SEC. L. REP. (CCH) If 95,013, at 97,541 (M.D. Fla. 1975) (nondisclosure in proxy materials of attempts to sell inajor assets); Pierre J. Lelandais \& Co. v. MDS-Atron, Inc., 387 F. Supp. 1310, 1328 (S.D.N.Y. 1974) (proxy did not disclose a substantial change in the nature of the business), modified, 543 F.2d 421 (2d Cir. 1976), cert. denied, 429 U.S. 1062 (1977); SEC v. Crofters, Inc., 351 F. Supp. 236, 242 (S.D. Ohio 1972) (concealment of inability to meet current obligations); Pappas v. Moss, 303 F. Supp. 1257, 1280 (D.N.J. 1969) (nondisclosure of financial turnaround and misrepresentations about the price and date of a sale of stock); Speed v. Transamerica Corp., 99 F. Supp. 808, 825-26, 828 (D. Del. 1951) (omission of facts regarding intent to liquidate); Ward La France Truck Corp., 13 S.E.C. 373, 378-81 (1943) (failure to disclose intent to hiquidate business). See also A. Bromberg \& L. Lowenfels, SeCurities Fraud and COMMODITIES Fraud \$§ 4.2, 5.2, 7.2 (1979); Brudney, A Note on Chilling Tender Solicitations, 21 RuTGERS L. Rev. 609, 635 n.61 (1967); Fleischer \& Mundheim1, Corporate Acquisition by Tender Offer, 115 U. PA. L. Rev. 317, 333-35 (1967); Note, SEC v. Texas Gulf Sulphur Co.: The Inside and Outside of Rule 10b-5, 46 B.U. L. REv. 205, 222-23 (1966).

A company or corporate official inight be sued not only for the omission or concealment of a contemplated closing, but also for the premature disclosure of an intent to close, particularly if the information proves incorrect. To avoid misrepresentation liability, corporations must eusure the accuracy of any disclosure concerning a partial closing. See, e.g., Shapiro v. Merrill Lynch, Pierce, Fenner \& Smith, Inc., 495 F.2d 228 (2d Cir. 1974).

138. 15 U.S.C. $\$ \S 78 \mathrm{a}-78 \mathrm{kk}$ (1976). 
impossible for the Board to state precisely when negotiations must begin, Board decisions have been contradictory and do not provide adequate guidance to employers. ${ }^{139}$ An employer who negotiates is still subject to the charge that the negotiations were untimely. ${ }^{140}$

The Board's remedies for failures to bargam over partial closings have also raised difficulties. Only rarely will it be practical for the Board to require a company to reopen its plant and rehire its employees. ${ }^{141}$ But the Board remedy of awarding back wages to all employees terminated as a result of the closing has sometimes been too harsh on employers. One reason is that the Board typically orders payment of back pay from the date of the refusal to bargain (the closing date) rather than from the date of the Board's decision. ${ }^{142}$ This is inappropriate when the question whether the bargaining obligation should have existed at all is a close one. Even in Fibreboard the Supreme Court approved the Board's award of back pay not from the date of the improper subcontracting but from the date of the Board's supplemental order requiring bargaining. ${ }^{143}$

The Board typically continues back-pay liability either until the company and union reach agreenent or until a bona fide impasse occurs. ${ }^{144}$ As noted, there is little likelihood that the parties will agree-

139. The test set out in Ozark Trailers requires bargaining "once [the employer] has reached the point of thinking seriously about taking such an extraordinary step as relocating or terminating a portion of his business." Ozark Trailers, Ine., 161 N.L.R.B. 561,569 (1966). Subscquent cases, however, have not shed light on the ineaning of this test. See notes 86-89 supra and accompanying text.

140. See note 134 supra.

141. See note 93 supra.

142. See National Family Opinion, Inc., 246 N.L.R.B. No. 84, 102 L.R.R.M. 1641 (1979); Caltrans Syss., 245 N.L.R.B. No. 90, 102 L.R.R.M. 1417 (1979); Ohio Brake \& Clutch Corp., 244 N.L.R.B. No. 5, 101 L.R.R.M. 1601 (1979); Victor Patino, 241 N.L.R.B. No. 76, 100 L.R.R.M. 1616 (1979). In Brockway Motor Trucks, 230 N.L.R.B. 1002, enforcement denied without prejudice 10 commencement of additional proceedings, 582 F.2d 720 (3d Cir. 1978), on remand, 251 NLRB No. 23, 104 L.R.R.M. 1515 (1980), and in Star Grocery Co., 237 N.L.R.B. 70 (1978), the Board modified its policy on back-pay orders when an employer refuses to bargaim over a partial closing. In both cases the Board held that the award of back wages should stop when the employer and union cominence bargaining rather than when the parties reach agreeinent or impasse. In National Family Opinion, Inc., 246 N.L.R.B. No. 84, 102 L.R.R.M. 1641, 1642 (1979), howvcr, the Board overruled this aspect of Brockway Motor Trucks and Star Grocery Co. and returned to the position that the back-pay award would run from the date of the refusal to bargain, measured from the date of closing. The award would run until the point of agreement or impasse, or until the union failcd to make a timely request for bargaining, or until the union bargained in bad faith.

143. Fibreboard Paper Prods. Corp. v. NLRB, 379 U.S. 203, 208, 215-17 (1964).

144. See National Family Opinion, Ine., 246 N.L.R.B. No. 84, 102 L.R.R.M. 1641, 1642 (1979); Caltrans Syss., Inc., 245 N.L.R.B. No. 90, 102 L.R.R.M. 1417, 1418 (1979); Ohio Brake \& Clutch Corp., 244 N.L.R.B. No. 5, 101 L.R.R.M. 1601, 1602 (1979); Victor Patino, 241 N.L.R.B. No. 76, 100 L.R.R.M. 1616, 1618 (1979); Metro Transp. Serv. Co., 218 N.L.R.B. 534 
particularly when the employer has already closed the plant and terminated the employees. Moreover, the time when a bona fide impasse occurs during negotiations is not always evident. ${ }^{145}$ Again, the union in such a situation will want to prolong bargaining and delay reaching an impasse in order to increase the back-pay liability.

The stated purpose of the Board's back-pay remedy is to restore the union's strength as it existed prior to occurrence of the unlawful act. 146 The Board remedy, however, frequently puts employees in a better position than if the company had met its bargaining obhigation. Generally, the employer would have closed the plant even if the company had negotiated; though the employer would have had to pay wages during the time spent bargaining, this period would be much shorter than the span covered by the Board's back-pay remedy. ${ }^{147}$ Pay-

(1975); Winn-Dixie Stores, 147 N.L.R.B. 788 (1964), enforced, 361 F.2d 512 (5th Cir. 1966). In these cases the Board ordered a company to offer to bargain with a union over the resumption of a closed busimess. It also ordered back pay to the employees terminated as a result of the closing from the time the employee was discharged until the first of the following events occurs: (1) the employer bargains to agreement with the union on the subjects pertaining to the decision to close and the effects of the closing on the employees; (2) a bona fide impasse in bargaining results; (3) the union fails to request bargaining within five days of the Board's decision or fails to commence negotiations within five days of the employer's notice of his desire to bargain with the union; or (4) the union fails to bargain in good faith.

In cases dealing with unlawful failures to bargain over effects of a closing, the Board usually orders back pay to commence five days after the date of its decision rather than the date of termination of the employee - on the theory that a make-whole remedy would be imappropriate when the facility would have closed regardless of bargaining. The back pay continues until the einployer reaches agreement with the union on the effects of the plant shutdown on its employees or until one of the other three conditions mentioned above occurs. In the "effect" cases, the Board also orders that in no event shall the sun paid to any employee exceed the amount he would have earned as wages from the date the employer terminated its operations to the time the employees secured equivalent employinent elsewhere or the date the employer offered to bargain, whichever occurs sooner. See, e.g., Vans Packing Plant, 211 N.L.R.B. 692 (1974).

145. An impasse exists when the Board finds that there is a substantial difference in the parties' positions over a significant issue and that the company and the union have exhansted all means of settlement. Taft Broadcasting Co., 163 N.L.R.B. 475 (1967), petition for review denied sub nom. American Fed. of Television \& Radio Artists v. NLRB, 395 F.2d 622 (D.C. Cir. 1968). See also NLRB v. Tex-Tan, Inc., 318 F.2d 472 (5th Cir. 1963); Fetzer Television v. NLRB, 317 F.2d 420 (6th Cir. 1963); Alsey Refractories Co., 215 N.L.R.B. 785 (1974). Courts and commentators have explained, however, that the time when negotiators reach an impasse is often difficult to determine. See Dallas Gen. Drivers Local No. 745 v. NLRB, 355 F.2d 842, 844-45 (D.C. Cir. 1966). See also NLRB v. Yama Woodcraft, Inc., 580 F.2d 942 (9th Cir. 1978); Schatzki, The Employer's Unilateral Act-A Per Se Violation-Sometimes, 44 TEX. L. Rev. 470, 495 (1966); Comment, Impasse in Collective Bargaining, 44 TEx. L. REv. 769 (1966).

146. See note 91 supra.

147. In other words, if an employer considered closing a plant on January 1 and bargained over the decision with the union until impasse was reached, as the Board requires, sce, e.g., E.1. DuPont De Nemours \& Co., 189 N.L.R.B. 753 (1971); G.W. Murphy Indus., 184 N.L.R.B. 62 (1971), perhaps three or four weeks of additional operations would be required. The employer would be required to pay two or three weeks additional wages, even if the employer on his own would have closed on January 1 . In contrast, if the employer had unilaterally announced a clos- 
ment of back wages froin the date of the failure to bargain in part gives employees what they would have received had their bargaining demands been met. The Board's remedy in partial-closing cases thus resembles the "make whole" remedy for an employer's failure to bargain in good faith over contract issues - a remedy the courts have uniformly rejected. ${ }^{148}$ Although the Board has broad remedial powers under the NLRA, it cannot assess penalties against an employer for a violation. ${ }^{149}$

ing on January 1 and the Board found that this decision violated section 8(a)(5), the employer's back-pay liability would run from the time of the closing and continue during Board proceedings; if the Board ordered the employer to negotiate, his back-pay liability would extend until agreement or impasse is reached with the union. This process could last for months, if not years. See, e.g., cases cited in notes 91-93 supra. See also 92 Harv. L. Rev. 768, 776 (1979).

148. In International Union of Electrical Workers v. NLRB (Tüdee Products, Inc.), 426 F.2d 1243 (D.C. Cir.), cert. denied, 400 U.S. 950 (1970), the Court of Appeals for the District of Columbia Circuit held that the Board could order a recalcitrant employer who had violated section 8(a)(5) to compensate employees for wage increases and fringe benefits that they arguably would have obtained through collective bargaining had the enployer not unlawfully refused to bargain. A similar "make whole" remedy was ordered by a trial examiner im a later case, but the Board rejected the trial examiner's proposed order and the reasoning of the District of Columbia Circuit in Tiidee Products. See Ex-Cel-O Corp., 185 N.L.R.B. 107 (1970), enforced, 449 F.2d 1058 (D.C. Cir. 1971). The Board rehed upon the Supreme Court's decision in H.K. Porter Co. v. NLRB, 397 U.S. 99 (1970), for the proposition that the Board lacked statutory authority to grant such a remedy. In H.K. Porter the Supreme Court held that the Board cannot order a party to imcorporate into a collective bargaming agreement a specific provision to which that party has not agreed. Id. at 107. The Board determined that a "inake whole" order would be punitive and speculative because the Board could not objectively determine what terms the parties would have agreed upon if an employer had promptly bargaincd, or indeed whethcr any agreement would liave been reached at all. See also Tiidee Products, Inc., 174 N.L.R.B. 705, 714 (1969), enforced in part and remanded in part sub nom, International Union of Electrical Workers v. NLRB, 426 F.2d 1243 (D.C. Cir.), cert. denied, 400 U.S. 950 (1970). Because the Supreme Court has subscquently held that the Board and not the courts of appeals have the primary responsibility for fashioning renedies, the Board's rejection of the "make whole" remedy has generally been followed. See NLRB v. Food Store Enrployees Local 347 (Heck's, Inc.), 417 U.S. 1 (1974); Winn-Dixie Stores Co., lnc. v. NLRB, 567 F.2d 1343, 1351 (5th Cir.), cert. denied, 439 U.S. 985 (1978); Tex Tan Welhausen Co. v. NLRB, 434 F.2d 405 (5th Cir. 1970), cert. denied, 402 U.S. 973 (1971). See also Bartosic \& Lanoff, Escalating the Struggle Against Taft-Hartley Contemnors, 39 U. CHI. L. REv. 255 (1972); Morris, The Role of the NLRB and the Courts in the Collective Bargaining Process: A Fresh Look at Conventional Wisdom and Unconventional Remedies, 30 VAND. L. REv. 661 (1977); St. Antome, $A$ Touchstone for Labor Board Remedies, 14 WAYNE L. Rev. 1039 (1968).

In NLRB v. W.R. Grace \& Co., 571 F.2d 279 (5th Cir. 1978), the Court affirmed the Board's finding that an employer violated its duty to bargain when it discontimued production of one material because of economic considerations and laid off four enployees without consulting the union. The -ourt rejected the Board's order (a common one in partial-closing cases) that the company place the terminated enployees on a preferential hiring list and offer reinstatement should it resume production. See note 92 supra. The court beheved that this would be tantanount to the Board compelling an agreement on a substantive contractual provision to which the parties did not agree, "on the basis of an assumption as to what the parties would have agreed to absent an employer's failure to bargain in good faith." 571 F.2d at 283.

149. Phelps Dodge Corp. v. NLRB, 313 U.S. 177 (1941); Republic Steel Corp. v. NLRB, 311 U.S. 7, 10-11 (1940); NLRB v. Fansteel Metallurgical Corp., 306 U.S. 240, 257-59 (1939). 
Perhaps the most serious deficiency in the Board's approach to partial closings has been its failure to consistently apply Ozark Trailers. After weighing the imterests of employers and employees when a plant is closed or relocated, the Board concluded in Ozark Trailers that the NLRA imposes a general duty on employers to bargain over such decisions. But in General Motors Corp., Royal Typewriter, and Brockway Motors, the Board has inconsistently apphed this policy. Such wavering by an administrative agency naturally makes a reviewing court suspicious of the agency's basic policy decision. ${ }^{150}$ Also, rather than adhering to its interpretation that the duty to bargain exists in all partial-closing cases or making its construction more flexible, the Board has handled the inore difficult cases, such as Kingwood Mining, BrooksScanlon, and International Offset Corp., by finding tortuous exceptions to its general rule. ${ }^{151}$ This type of ad hoc decision-making makes it difficult for employers and unions to predict the Board's approach in a particular plant-closing situation.

\section{B. The Deficiencies of the Courts of Appeals' Approach .}

Though the Board's approach to partial closings has been inconsistent and in many respects unsound, the appellate court decisions in this area have misapplied the National Labor Relations Act and have misconstrued the purposes of collective bargaining. As the Court of Appeals for the Eighth Circuit clearly stated in NLRB v. William J. Burns International Detective Agency, Inc., ${ }^{152}$ courts will not find a violation of an employer's section 8(a)(5) duty to bargain under Fibreboard unless the einployer also violates section $8(a)(3)$ by closing an operation with the requisite improper motive under Darlington. ${ }^{153}$ As a result, an employer will seldom be required to bargain over plant shutdowns or relocations, both because the Darlington standards of proof are very difficult to meet and because an employer will usually have some econo1mic justification for closing a plant.

150. In General Elec. Co. v. Gilbert, 429 U.S. 125, 143 (1976), the Supreme Court rejected the Eqnal Employment Opportunity Commission's imterpretation of Title VII of the 1964 Civil Rights Act of 1964,42 U.S.C. $\$ 2000 \mathrm{e}-2$ (a)(1) (1976), regarding pregnancy discrimination, im part because the interpretation conflicted with an earlier determination of the Commission: "We have declined to follow administrative guidelines in the past where they conflicted with earlier pronouncements of the agency." See also United Housing Foundation v. Forman, 421 U.S. 837, 858-59 n.25 (1975); Espimozah v. Farah Mfg. Co., 414 U.S. 86, 92-96 (1973).

151. See notes 107-19 supra and accompanying text.

152. 346 F.2d 897 (8th Cir. 1965).

153. Id. at 902. Some judges still loold this view. See, e.g., Davis v. NLRB, 617 F.2d 1264, 1274-75 (7th Cir. 1980) (Pell, J., dissenting). 
The appellate courts' analysis confuses some of the basic distinctions between sections 8(a)(3) and 8(a)(5) of the NLRA. When unilateral employer action undermines a union's ability to represent its members, subjective bad faith against the union is unnecessary for a finding that the employer breached section $8(a)(5) .{ }^{154}$ The elimination of all or substantially all jobs without bargaining, as im a closing, certainly impairs the union's ability to function as the collective bargaining representative, regardless of the employer's economic inotivation. Indeed, in Fibreboard, which imvolved a termination of jobs through subcontracting, the Supreme Court did not make illegal motive an eleinent of a refusal-to-bargam offense under section 8(a)(5). . $^{155}$

Moreover, the gravamen of a section 8(a)(3) offense differs significantly from that of a section $8(a)(5)$ offense. The imjury in a discrimination case is primarily to individual employees and only secondarily, if at all, to the union. ${ }^{156}$ The typical remedy im section 8(a)(3) cases is to coinpensate the individual victims of discrimination for the financial injury caused by the illegal act. ${ }^{157}$ In addition, the Board generally orders the employer to act with a proper justification toward employees in the future. In a refusal-to-bargain case, on the other hand, the mjury is essentially to the union. The typical remedy im these cases is to require the employer to meet its obligation to bargain in good faith. ${ }^{158}$ If

154. In NLRB v. Katz, 369 U.S. 736 (1962), the Board found that an employer committed an unfair labor practice under section 8 (a)(5) by implementing changes in wages and sick leave without bargaining with the union. There was no finding of bad faith in the failure to negotiate. Nevertheless, the Court upheld the Board's finding. See also H.J. Heinz Co. v. NLRB, 311 U.S. 514 (1941); Electri-Flex Co. v. NLRB, 570 F.2d 1327 (7th Cir.), cert. denied, 439 U.S. 911 (1978); Buffalo Bituminous, Inc. v. NLRB, 564 F.2d 267 (8th Cir. 1977); Rust Craft Broadcasting of N.Y., Inc., 225 N.L.R.B. 327 (1976).

155. Fibreboard Paper Prods. Corp. v. NLRB, 379 U.S. 203 (1964), did not require the Board to find an illegal motive before concluding that an employer violated its section 8(a)(5) duty to bargain. See also Davis v. NLRB, 617 F.2d 1264, 1270 (7th Cir. 1980); Brockway Motor Trucks v. NLRB, 582 F.2d 720, 735 (3d Cir. 1978), on remand, 251 N.L.R.B. No. 23, 104 L.R.R.M. 1515 (1980); East Bay Union of Machinists, Local 1304 v. NLRB, 322 F.2d 411, 414 (D.C. Cir. 1963) ("It is not necessary to find an anti-union animus as a predicate for a conclusion that the employer [who unilaterally subcontracted out bargaining-unit work] violated Section 8(a)(5)"). Bliss, supra note 27, at 272-73.

156. Section 8(a)(3) states that it is an unfair labor practice to discriminate "in regard to hire or tenure of employineut or any term or condition of employinent." 29 U.S.C. § 158(a)(3) (1976). Of course, a company einploys only an individual, not a uniou. On the other hand, section 8(a)(5) forbids an employer from refusing to bargain "with the representatives of his employees." Id. § 158(a)(5).

157. As the Supreme Court stated in Phelps Dodge Corp. v. NLRB, 313 U.S. 177, 197 (1941); "Making the workers whole for losses suffered on account of an unfair labor practice is part of the vindication of the public policy which the Board enforces." See also NLRB v. J.H. Rutter-Rex Mfg. Co., 396 U.S. 258, 263 (1969); Nathanson v. NLRB, 344 U.S. 25, 27 (1952).

158. "The usual reinedy for an einployer's refusal to bargain in violation of Section 8(a)(5) is an order (1) to cease and desist froin failing to bargain and (2) upon request, to bargain collec- 
section 8(a)(3) were applied to partial-closing cases, tlie einployer would be required to reinain in business until its anti-union animus had dissipated and it could prove it had a legitimate reason for going out of business. Section 8(a)(5), however, would allow an einployer to cease operations once it had met its duty to bargain in good faith. ${ }^{159}$ Finally, even when the einployees receive inonetary dainages for an employer's failure to bargain over a partial closing, the purpose of the award is not to remedy an injury to the einployees but rather to restore the union's bargaining strength in negotiations over the closing decision. ${ }^{160}$ These basic distinctions in the two sections of the Act show that section $8(a)(5)$, rather than section $8(a)(3)$, is the proper section under which to analyze the duty to bargain in partial-closing cases.

Soine courts have interpreted the language of section $8(\mathrm{~d})$, which does not include partial closings in the list of required subjects of bargaining, and the legislative history behind the section, to inean that there is no duty to negotiate concerning sliutdown decisions. ${ }^{161}$ This theory misconstrues congressional intent regarding mandatory subjects of bargaining. When Congress ainended the NLRA in 1947, section 2(11) of the House bill carefully listed the subjects over which unions and employers were required to bargain, stating that these were the only topics that the partics needed to discuss. ${ }^{162}$ The House Report specified that the bill so limited mandatory items of negotiation to insulate employers froin bargaining over how the business was run. ${ }^{163}$ The

tively regarding rates of pay, wages, hours, and other conditions of employment." C. MORRIS, supra note 9, at 857. See also NLRB v. Katz, 369 U.S. 736 (1962).

159. See Rabin, supra note 27 , at 820 .

160. See notes 91 \& 144 supra.

161. See note 66 supra and accompanying text.

162. The version that initially passed the House, H.R. No. 3020 , stated:

Such terms shall not be construed as requiring that either party reach an agreement with the other, accept any proposal or counterproposal either in whole or in part, submit counterproposals, discuss modification of an agreement during its terns except pursuant to the express provisions thereof, or discuss any subject matter other than the following: (i) wage rates, hours of employment and work requirements; (ii) procedures and practices relating to discharge, suspension, layoff, recall, seniority and discipline, or to promotion, demotion, transfer and assignment within the bargaining unit; (iii) conditions, procedures, and practices governing safety, sanitation, and protection of health at the place of employment; (iv) vacations and leaves of absence; and (v) administrative and procedural provisions relating to the foregoing subjeets.

H.R. No. 3020, 80th Cong., 1st Sess. § 2(11) (1947) (emphasis added); see also H.R. REP. No. 245,

80th Cong., 1st Sess. 22-23, 49 (1947).

163. The House Report stated:

[T]he umion has no right to bargain with the employer about who his agents will be, what prices he will charge, what his profits shall be, or how he shall manage his business, so long as he does not violate the union's contract with him or ignore his obligations under the Labor Act.

H.R. REP. No. 245 , supra note 162 , at $22-23$. 
Senate version, ${ }^{164}$ however, contained no provision similar to the House's section 2(11) and the conference committee rejected the House provision as an attempt to "straightjacket" and to "limit narrowly the subject matters appropriate for collective bargaining." 165 The final bill deleted the House section and used the more general language of the Senate version, which now appears as section 8(d). ${ }^{166}$

In other contexts courts have approved of a flexible approach to mandatory bargaining issues and have realized that some matters evolve into mandatory subjects of negotiation because of social needs, industrial experience, or technological advancement. ${ }^{167}$ For exainple, at one time the Supreme Court held that stock purchase plans, group insurance, and inedical insurance were matters outside the scope of required discussions between companies and unions. ${ }^{168}$ Today these items are not only mandatory subjects of bargaining, but are at the heart of negotiations between compaines and unions. ${ }^{169}$ In choosing the less restrictive approach to the scope of the collective bargaining duty, Congress delegated the primary task of determining the proper boundaries of the bargaining obhgation to the National Labor Relations Board. ${ }^{170}$ The legislative history does not support the suggestion

164. S. 1126, 80th Cong., 1st Sess. (1947).

165. S. Rep. No. 105, 80th Cong., 1st Sess. 71 (1947). The Senate explicitly rejected the House proposal and stated in its report:

This section [\$2(11)] attempts to limit narrowly the subject matters appropriate for collective bargaining. It seems clear that the definitions are designed to exclude collective bargaining coneerning welfare funds, vacation funds, union hiring halls, union security provisions, apprenticeship qualifications, assignment of work, checkoff provisions, subcontracting of work, and a host of other matters traditionally the subject matter of collective bargaining in some industries or in certain regions of the country. The appropriate scope of collective bargaining cannot be determined by a formula; it will inevitably depend upon the traditions of an industry, the social and political climate at any given time, the needs of employers and employees, and many related factors. What are proper subject matters for collective bargaining should be left in the first instance to employees and trade unions, and in the second place, to any administrative agency skilled in the field and competent to devote the necessary time to a study of industrial practices and traditions in each imdustry or area of the country, subject to review by the courts. It cannot and slould not be straitjacketed by legislative enactment.

Id. (emphasis added). See also H.R. REP. No. 245, supra note 162, at 22-23; 93 CoNG. REC. 3649 50 (1947) (remarks of Rep. Norton).

166. S. 1126, 80th Cong., 1st Sess. § 8(d) (1947) (codified at 29 U.S.C. § 158(d) (1976)); see 93 CONG. REC. 6444 (1947) (summary report of Sen. Taft).

167. See, e.g. , Ford Motor Co. v. NLRB, 441 U.S. 488 (I979). See also notes 10-26, 165 supra, I80-82 infra and accompanying text. Industrial experience, one of the factors the Supreme Court relied on in Fibreboard, 379 U.S. at 211-12, has favored contractual clanses requiring notice and bargaining before closing a plant. See Rabin, supra note 27, at $822-23$ (over $21 \%$ of contracts in a 1969 Bureau of Labor Statistics Survey contained some express restriction on manageinent's right to terminate or transfer operations).

168. J.I. Case Co. v. NLRB, 321 U.S. 332, 339 (1944).

169. See notes 12-14, 23 supra. See also R. Rowan, Collective Bargaining: Survival in THE '70s? 359, 371 (1972).

I70. See note 165 supra. 
that the Board is without power to define the issues that parties must discuss prior to implementation. On the contrary, the legislative history indicates that the appellate courts should defer to the Board's administrative expertise im defining the expanding concept of mandatory subjects of bargaining. ${ }^{171}$

Most appellate court decisions also misperceive the role of collective bargaining in our labor relations system. These courts have focused on partial closings only from the viewpoint of management. The test appellate courts apply ${ }^{172}$ recognizes as relevant considerations only the employer's tangible capital mvestment and the need to minimize loss to investors in a business that has become unprofitable. According to the courts the most efficient way to minimize financial mjury to a company and its shareholders is to allow inanagement to decide quickly and unilaterally when an operation should be terminated. This analysis, however, overlooks the intangible investments inade by the workers. The service capital supplied by employees is as necessary to a business as the property capital supplied by imvestors. ${ }^{173}$ The employees' commitment to a coinpany often imvolves years of training, the development of specialized skills, and the ordering of their lives around an einployer's busmess. Certainly any prudent management would not decide to hquidate or move its own investinent without extensive financial and legal advice from many experts. ${ }^{174}$ Similarly, a company should not be allowed to destroy the imvestinent of employees through permanent job terminations associated with a shutdown, without providing workers an opportunity to participate in the decision-making process through collective bargaining.

One of the fundamental purposes of the NLRA is to encourage a sharing of decision-inaking im areas affecting both the employer and the employees in order to reduce imdustrial strife. ${ }^{175}$ Senator Wagner explamed the philosophy behind the duty to bargain as the implementation of "democracy in mdustry [, which] ineans fair participation by those who work in the decisions vitally affecting their lives and liveli-

171. This was stated recently by the Supreme Court in Ford Motor Co. v. NLRB, 441 U.S. 488, 496 (1979).

172. For a description of the test used by the appellate courts, see notes 59-69 supra and accompanying text.

173. For a discussion of such worker and employer investment, compare Green, The Case for the Sit-Down Strike, 90 NEw REPuBL1C 199-200 (1937) with Comment, supra note 75, at 1091-95. As to the effects a large plant closing can have on employees, unions, and the surrounding community, see Sease, Closing of a Steel Mill Hits Workers in U.S. With Little Warning, Wall St. J., Sept. 23, 1980, at 1, col. 6 .

174. See notes 129-30 supra and accompanying text.

175. 29 U.S.C. $\S 151$ (1976). 
hood . . ."176 Certainly a decision causing the total loss of bargaining-unit jobs and the ousting of the employees' collective bargaining representative vitally affects both workers and their unions. If the NLRA requires an employer to bargaim with a union over such relatively mundane items as the prices of goods in a vending machine because of their effect on the terms and conditions of employment, ${ }^{177}$ it should also require negotiations over the very livelihood of workers. ${ }^{178}$

The courts of appeals' test does not adequately take into account the rationale behind the duty to bargain under the NLRA. The foundation of the courts' theory has imstead been economic efficiency. ${ }^{179}$ Courts have feared that the imconvenience and delay caused by negotiations will reduce or eliminate opportunities to shift capital to more profitable investments or to minimize losses. Yet courts have long realized that collective bargaining obligations may cause economic loss. For exaunple, under the Act an employer must bargain with the union over a work-preservation clause; this not only hinders but could even prevent technological advance in an industry. ${ }^{180}$ The Supreme Court has held that collective bargaining im such instances is the favored

176. M. Derber, The American Idea of Industrual Democracy 321 (1970) (citing N.Y. Times, Apr. 13, 1937, at 20, col. 1).

177. Ford Motor Co. v. NLRB, 441 U.S. 488 (1979).

178. Such a duty to negotiate would not change the basic structure of collective bargaining by raising unions to the level of managenent, though some commentators have so argued. See, e.g., Goetz, supra note 27 , at 10 . Giving employee representatives an opportunity to negotiate before the closing of a plant hardly amounts to the co-determination approach adopted im some European countries. See Summers, Worker Participation in the U.S. and West Germany: A Comparative Study from an American Perspective, 28 AM. J. Comp. L. 367 (1980); von Boehmer, The New Co-Determination Act in West Germany (pt. 1), 121 Solicitors' J. 485 (1977); Wiedemann, Codetermination by Workers in Gcrman Enterprises, 28 AM. J. COMP. L. 79 (1980). Unions would not become directors of a company with responsibility for such management functions as layoffs, pricing, marketing, or the inethod of production. Rather, workers would be given only a traditional forum-collective bargaining -in which to voice their concerns about an issue of the highest importance to thein. Once the employer has bargained in good faith over the partial closing, it could implement its determination regardless of the union's objections. In fact, by allowing the assertion of euployee ideas about a partial closing through negotiations, the parties would not only fulfill the principles of industrial democracy that underlie the NLRA but also might preserve the collective bargaining system from more drastic changes in directions such as co-determination.

179. See notes 62-69 supra and accompanying text.

180. In National Woodwork Mfrs. Ass'n v. NLRB, 386 U.S. 612 (1967), a construction contractor and a carpenters' union negotiated a clause that prevented the contractor fronı using doors that had been fitted before being furnished for installation. The Court found this work-preservation clause to be lawful because it protected the job-site work of the carpenters, even though it stood in the way of innovation. See also NLRB v. Enterprise Ass'n of Pipefitters, 429 U.S. 507 (1977); NLRB v. Gamble Enterprises, 345 U.S. 117 (1953); American Newspaper Publishers Ass'n v. NLRB, 345 U.S. 100 (1953); St. Antoine, Secondary Boycotts and Hot Cargo: A Study in Balance of Power, 40 U. DET. L.J. 189 (1962); 90 HARV. L. REV. 815 (1977). 
means to handle the displacement of workers by modernization. ${ }^{181}$ The balance struck in the work-preservation context demonstrates that our system of labor relations prefers negotiations to unilateral decisions that permanently displace workers, even if the negotiations sacrifice some economic efficiency. ${ }^{182}$

Some courts have also stated that bargaining over plant closings is futile because economic considerations ultimately dictate the outcome, and because the complex financial issues mvolved are beyond the unions' expertise. ${ }^{183}$ The obligation to bargain under the NLRA, lowever, does not require that the employer and union reach agreement; it requires only that they negotiate im good faith to an impasse. Although the parties are expected to make a reasonable effort to agree, the possibility rather than the probability of agreement is the statutory standard to determine if a bargaining obligation should exist. ${ }^{184}$

Employees and umions have frequently played a pivotal role in keeping a busimess functioning or a plant open. ${ }^{185}$ Employees liave often agreed to forego or defer wage and benefit increases or to make other concessions to save a plant and thereby their jobs. ${ }^{186}$ The most pronounced example of such action is the recent efforts by the United Auto Workers to contribute to the rescue of the Chrysler Corporation. ${ }^{187}$ In other situations labor organizations and employees liave in-

181. See NLRB v. International Longshoremen's Ass'n, 100 S. Ct. 2305, 2314 (1980). This view directly contradicts Justice Stewart's concurring opinion in Fibreboard that Congress intended to place the decision about automation and technological change solely in the hands of management. See note 47 supra and accompanying text.

182. There is scant proof, however, that requiring bargaining over a decision to close will in fact hinder capital movement. See 92 HARv. L. Rev. 768, 775-76 (1979).

183. See notes $80-81$ supra and accompanying text.

184. See Brockway Motor Trncks, 251 N.L.R.B. No. 23, 104 L.R.R.M. 1515 (1980). See also Brooks-Scanion, Inc., 246 N.L.R.B. No. 76, 102 L.R.R.M. 1606 (1979) (Murphy, M., dissenting).

185. See, e.g., Midland-Ross v. NLRB, 617 F.2d 977, $982-83$ (3d Cir.), cert. denied, 101 S. Ct. 210 (1980); Brockway Motor Trucks v. NLRB, 582 F.2d 720, 735-36 (3d Cir. 1978), on remand, 251 N.L.R.B. No. 23, 104 L.R.R.M. 1515 (1980); Ozark Trailers, Inc., 161 N.L.R.B. 561, 569-70 (1966); Rabim, supra note 27, at 823-26; Rabin, supra note 62, at 156.

186. For example, under threat of closing the plant because of poor financial conditions, employees at Uniroyal, Inc., represented by the United Rubber Workers recently agreed to a wage and benefit reduction plan that reduced the firm's labor costs by $12.9 \%$ over 17 months. BNA News and Background Information. 104 Lab. Rel. Rep. $267-68$ (1980). Steelworkers at Kaiser Steel Corporation have agreed to similar reductions, BNA News and Background Information, 105 Lab. Rel. Rep. 38 (1980), as have employees at Wheehing-Pittsburg Steel Corporation, Wall St. J., Feb. 15, 1980, at 4, col. 5.

187. In bargaining for the labor contract that was signed on October 25,1979 , the United Auto Workers made numerous concessions to the Chrysler Corp. that it had not made to General Motors Corp. or Ford Motor Co., whose contracts were negotiated earher. Among these were: (1) delayed imcreases in basic wages, which saved $\$ 203$ million; (2) quarterly rather than weekly payments of cost-of-living allowance increases, which were estimated as equivalent to a $\$ 35$ million-ayear loan; (3) one year deferral of $\$ 200$ million in pension contributions; and (4) acceptance of 20 
vested their own funds in the einployer's business to help avoid a shutdown. ${ }^{188}$ Bargaining may also convince management that laborrelated closing costs, such as payment of accrued benefits for severance, vacations, and hohdays, are greater than the savings that would result from ceasing plant operations. ${ }^{189}$ Even if the union cannot overturn the closing decision, the timing and method of announcing the decision to close may be negotiated in order to lessen the adverse impact on employees. ${ }^{190}$ Umions might also bargain with the company to delay the closing in order to find a purchaser of the operation and thus save the employees' jobs. ${ }^{191}$

Indeed, rather than damaging employee morale and discipline, frank discussions with unions prior to a decision to close may have the opposite effect. The Wilson Freight Company recently asked its 3400 employees to make substantial personal investments in the company im order to stave off bankruptcy. More than $97 \%$ of the workers responded by signing preliminary stock subscriptions for $\$ 10.7$ million. Further, management reported that inorale among employees improved considerably once laborers realized the financial plight of the

paid holidays rather than the 26 that were negotiated with General Motors and Ford. LAB. REL. YEARBooK 5 (1979); N.Y. Times, Oct. 26, 1979, § D, at 6, col. 3; Wall St. J., Oct. 26, 1979, at 3, col. 1.

Additionally, the UAW members of the Chrysler Corp. recently ratified a freeze on wages and pension benefits through September, 1982, and an immediate rollback on all cost-of-living adjustments for the remainder of the contract term. It has been calculated that this will save the corporation over $\$ 670$ million in labor costs. The employees' sacrifices were necessary to qualify Chrysler for federally-guaranteed loans that the company needed to remain in business. BNA News and Background Information, 105 Lab. Rel. Rep. 339 (1980); Wall St. J., Jan. 15, 1981, at 3, col. 1; Wall St. J., Jan. 20, 1981, at 5, col. 1.

188. Brockway Motor Trucks v. NLRB, 582 F.2d 720, 736 n.n. 89, 90 (3d Cir. 1978), on remand, 251 N.L.R.B. No. 23, 104 L.R.R.M. 1515 (1980); BNA News and Background Information, 104 Lab. Rel. Rep. 239 (1980) (company stockholders of Rath Packing Co. of Waterloo, Iowa, approved selling a controlling imterest to employees and added 10 union-nominated directors to the 16-meinber board to avert a shutdown); Wall St. J., Aug. 1, 1980, at 4, col. 5 (employee loans to Cooper-Jarrett, Inc., a trucking firm, in order to contmue operation); Wall St. J., June 10, 1964, at 10, col. 5 (UAW local invests in Divco-Wayne Corp., a bus production firm, and agrees to take wage cuts and change work rules to keep plant from closing and transferring its operations).

189. See Brockway Motor Trucks v. NLRB, 582 F.2d 720, 736 (3d Cir. 1978), on remand, 251 N.L.R.B. No. 23, 104 L.R.R.M. 104 (1980). These costs can mount quite rapidly and be a significant factor in a closing decision. For instance, United Merchants, a textile company, recently agreed to pay $\$ 1.4$ million to three unions for distribution to 5,000 former employees as severance pay. Wall St. J., Aug. 9, 1980, at 12, col. 4.

190. Brockway Motor Trucks v. NLRB, 582 F.2d 720, 736 (3d Cir. 1978), on remand, 251 N.L.R.B. No. 23, 104 L.R.R.M. 1515 (1980).

191. See, e.g., United Steelworkers Local 1330 v. Umited States Steel Corp., 492 F. Supp. 1 (N.D. Ohio), aff'd in part and rev'd in part, 631 F.2d 1264 (6th Cir. 1980) (the employees and the union sought to enter into purchase negotiations with United States Steel when the company announced the closing of its Youngstown plant and the termination of 3500 employees). 
company and the role they could play in saving their jobs. ${ }^{192}$

The argument that unions cannot understand the financial aspects of a business closing is also erroneous. Uinon representatives must have a sophisticated understanding of finance and investment in -order to negotiate with employers. Furthermore, unions directly or indirectly control the investments of billions of dollars in pension, health and welfare, and other benefit funds. ${ }^{193}$ There is no lack of financial expertise in most labor organizations.

The courts' presumption that bargaining over a decision to close would be ineffectual substitutes a judicial conclusion for the possibility of an agreement between the parties. By holding that an employer need not bargam about a partial closing, the courts preordain the outcome: the plant will close. Even if it is improbable that the company and union would agree on measures to keep a plant in business, the NLRA requires that the opportunity to agree should be left to the parties, not foreclosed by the courts.

Even legitimate management interests im partial closings, such as confidentiality and timing, are overstated by the courts. Although many courts rely on these factors to find no obligation to negotiate, there has not been a single case in which an employer has shown a necessity for secret or expeditious action that would render its negotiations prior to a decision impracticable. ${ }^{194}$ For example, International Association of Machinists $v$. Northeast Airlines ${ }^{195}$ concerned a merger that resulted in a plant shutdown and the attendant loss of jobs. The court found no duty to bargain, stating that "merger negotiations require . . . secrecy, flexibility and quickness . . . ."196 The company did not, however, actually prove any of these interests. The court noted that the company had engaged in merger discussions with another airline on four previous occasions. Thus, one can hardly say time was of the essence or that the possibility of a inerger was a well-kept secret. Also, before the merger could be consummated, the company needed

192. Wall St. J., July 3, 1980, at 19 , col. 4 .

193. Most estimates show that as of 1978 there was over $\$ 500$ billion in pension funds and that such funds were growing at the rate of approximately $10 \%$ per year. J. RIFXIN \& R. BARBER, THE North Will Rise Again 234 n.13 (1978); Bureau of the Census, United States Dep't of Com., Statistical AbStract of the Unired States: 1979, No. 545, at 340 . By the late 1980s, pension fund portfolios could be worth \$1.3 trillion. Raskin, Pension Funds Could Be the Unions' Secret Weapon, Fortune, Dec. 31, 1979, at 64. One authority has estimated that unions, or unions and employers together, controlled at least $\$ 200$ billion of pension funds in 1978. J. RIFKIN \& R. BARBER, supra, at 235 n.16.

194. See notes 59-69 \& 74-95 supra and accoinpanying text.

195. 473 F.2d 549 (1st Cir.), cert. denied, 409 U.S. 845 (1972). See notes 76-77 supra and accompanying text.

196. 473 F.2d at 557. See text accompanying notes 76-77 supra. 
the approval of its shareholders and of the Civil Aeronautics Board. There was no evidence that discussions with the union prior to the final decision would jeopardize the merger or cause leaks of information. Before they rely on secrecy and speed to allow a company to refuse to bargain, courts should require the company to show that a need for secrecy or speed actually exists. ${ }^{197}$ Even if these needs are present, the Board and the courts can use alternate means to ensure that employees or their representatives do not unduly delay proceedings or divulge privileged information. ${ }^{198}$

The courts of appeals' attitude toward the need for confidentiahity in partial closings is somewhat puzzling in view of their holdings on bargaining over the effects of closings. As noted previously, the courts agree with the Board that employers have a duty to bargain with unions over the effects of a partial closing. ${ }^{199}$ This obligation includes not only the requirement to discuss the effects of the closing, but also to give timely, prior notice of the bargaining subject. ${ }^{200}$ In most cases the coinpany will thus reveal information about the decision to close prior to its implementation. Such notice to bargain over the effects of the closing eliminates the element of secrecy as completely as would notice to bargain over the decision to close.

\section{Proposal}

Both the Board's and the appellate courts' current approaches to the duty to bargain in partial shutdowns are too inflexible to weigh properly the competing interests of manageinent and labor. A uniform approach must be adopted that balances all the parties' legitimate interests and that also takes into account the specific facts of each case. One device that the Board has used in other areas that requires a flexible approach is the evidentiary presumption. ${ }^{201}$ When the Board's ex-

197. See, e.g., NLRB v. First Nat'l Maintenance Corp., 627 F.2d 596 (2d Cir. 1980), cert. granted, 49 U.S.L.W. 3480 (U.S. Jan. 13, 1981) (No. 80-544); Davis v. NLRB, 617 F.2d 1264 (7th Cir. 1980); Midland-Ross Corp. v. NLRB, 617 F.2d 977 (3d Cir.), cert. denied, 101 S. Ct. 210 (1980); Brockway Motor Trucks v. NLRB, 582 F.2d 720 (3d Cir. 1978), on remand, 251 N.L.R.B. No. 23, 104 L.R.R.M. 1515 (1980).

198. See notes $214-20$ infra and accompanying text.

199. See notes 28-29 supra and accompanying text. See also Royal Typewriter Co. v. NLRB, 533 F.2d 1030 (8th Cir. 1976); Morrison Cafeterias Consol., v. NLRB, 431 F.2d 254 (8th Cir. 1970); NLRB v. Drapery Mfg. Co., 425 F.2d 1026 (8th Cir. 1970); NLRB v. Thompson Transp. Co., 406 F.2d 698 (10th Cir. 1969); NLRB v. Transmarine Navigation Corp., 380 F.2d 933 (9th Cir. 1967); NLRB v. Royal Plating \& Polishing Co., 350 F.2d 191 (3d Cir. 1965).

200. See 29 U.S.C. \& 158(d) (1976); Rabin, supra note 62, at 155.

201. A rebuttable presumption is a device to shift "the burden of producing evidence, and . . . under the preferable view operates to assign the burden of persuasion as well." C. MCCoRMicK, HANDBOOK OF THE LAW OF EVIDENCE 806 (2d ed. E. Cleary 1972). For a decision upholding the 
perience with a particular problem reveals a clear pattern, it often has established rebuttable presumptions to allocate the burden of proof. For example, the Board has declared that an employer's rule banning union solicitation of workers by other workers is presumptively valid when applied during work time on the company's premises, but presumptively invalid with respect to employees who are not on coinpany time. ${ }^{202}$

The Court of Appeals for the Third Circuit recently encouraged the use of presuniptions with regard to the duty to bargain over a decision to close a plant for economic reasons. The court in Brockway Motor Trucks v. $N L R B^{203}$ concluded that a partial closing that resulted in job terminations fell within the hteral meaning of affecting "terins and conditions of employment" and that negotiations over the decision to close would help avoid industrial conflict. The court therefore held that in a partial-closing situation the first step is to presume that the decision to close is a mandatory subject of bargaining. Next, stated the court, the facts of the case should be considered carefully to determine if the inference is justified. ${ }^{204}$

NLRB's use of rebuttable presumptions, see, e.g., Republic Aviation Corp. v. NLRB, 324 U.S. 793,804 (1945). Some have criticized the Board's use of rebuttable presumptions rather than its formal rulemaking powers under section 6 of the Act, 29 U.S.C. $\$ 156$ (1976). See Bernstem, The NLRB's Adjudication-Rule Making Dilemma Under the Administrative Proeedure Act, 79 YALE L.J. 571 (1970); Peck, A Critique of the National Labor Relations Board's Performance in Policy Formulation: Adjudication and Rule-Making, 117 U. PA. L. REv. 254 (1968); Peck, The Atrophied Rule-Making Powers of the National Labor Relations Board, 70 YALE L.J. 729 (1961). But see Note, NLRB Rulemaking: Political Reality Versus Procedural Faimess, 89 YALE L.J. 982 (1980).

202. See Peyton Packing Co., 49 N.L.R.B. 828 (1943), enforced, 142 F.2d 1009 (5th Cir. 1944), cited with approval in Republic Aviation Corp. v. NLRB, 324 U.S. 793, 803 n.10 (1945). See also Eastex, Inc. v. NLRB, 437 U.S. 556 (1978). The Board has created many other rebuttable presumptions with respect to organizational solicitations. See, e.g., Stoddard-Quirk Mfg. Co., 138 N.L.R.B. 615, 620-21 (1962); Marshall Field \& Co., 93 N.L.R.B. 182, 183 (1951).

The Board lias established rebuttable presumption rules in other areas. See Retired Persons Pharmacy v. NLRB, 519 F.2d 486 (2d Cir. 1975) (presumption of majority status); NLRB v. Lorben Corp., 345 F.2d 346 (2d Cir. 1965) (polling of employees by einployer is presumptively unlawful); Struksnes Constr. Co., 165 N.L.R.B. 1062 (1967) (polling of employees by employer is presumptively unlawful).

203. 582 F.2d 720 (3d Cir. 1978), on remand, 251 N.L.R.B. No. 23, 104 L.R.R.M. 1515 (1980).

204. 582 F.2d at 735. The Second Circuit followed this approach in NLRB v. First Nat'l Maintenance Corp., 627 F.2d 596 (2d Cir. 1980), cert. granted, 49 U.S.L.W. 3480 (U.S. Jan. 13, 1981) (No. 80-544), as did the Third Circuit in Midland-Ross Corp. v. NLRB, 617 F.2d 977 (3d Cir.), cert. denied, 101 S. Ct. 210 (1980). The Sixth and Seventh Circuits have cited Brockway Motor Trucks with approval. Davis v. NLRB, 617 F.2d 1264, 1270 (7th Cir. 1980); NLRB v. Production Molded Plastics, Inc., 604 F.2d 451, 453 n.1 (6th Cir. 1979).

In First National Maintenance the Second Circuit seemed to disagree with Brockway Motor Trucks about the imterests that a court should consider in presuming bargaining to be required. It found that the NLRA's bargaining requiement slould be paramount, rather than the relative economic injury to the employer vis-a-vis the employees. $627 \mathrm{~F} .2 \mathrm{~d}$ at 601 . A close reading of Brockway Motor Trucks shows, however, that the Third Circuit considered both factors. This 
The Third Circuit's rule in partial-closing cases is an example of properly using rebuttable presumptions. A coinpany generally shuts down an operation because the costs of production have outstripped the income from the sale of the product. ${ }^{205}$ Labor-related costs are the largest component of the cost of producing a commodity. ${ }^{206}$ In most cases, if the employer can reduce his labor costs below a certain point the operation can again become profitable and the need for a shutdown can be avoided. Because labor costs are within the jomt control of companies and umions and are clearly mandatory subjects of bargaming under the NLRA, ${ }^{207}$ negotiations over the amount of wages and benefits paid can affect the decision to close. Given the importance of a shutdown to both management and labor, and considering that the primary reason for closing is typically a negotiable subject, a rebuttable presumption that an employer and a umion should bargain over a decision to close is proper.

If the employer fails to bargain over a decision to close, he should bear the burden of proving that the primary reason for the closing was an economic necessity outside the employment relation. ${ }^{208}$ Antiquated plant equipment, the loss of an essential source of supply, or the inability to meet the demands of a customer can cause shutdowns and are unlikely to be affected by negotiations with the workers. To require bargaining in these instances would be futile and would fulfill no valid purposes of the Act. Similarly, in some cases an employer may be able to demonstrate that bargaining would result im irreparable harin because of a need for immediate action or confidentiality. If a company

approach is appropriate. For instance, if an employer unexpectedly lost its major source of credit, it could suffer irreparable harm if required to remain open until it bargained with the union. To require bargaining, however, might fulfill the purposes of the NLRA because the union might be willing to supply the necessary funds until another credit source was found. But even the Board has not required negotiations over the decision to close when to do so would cause overriding financial harm to the employer. Raskin Packing Co., 246 N.L.R.B. No. 15, 102 L.R.R.M. 1489 (1979); M \& M Transp. Co., 239 N.L.R.B. 73 (1978).

205. If a company shuts down onc of its operations for anti-union reasons, the Darlington test applies. See notes 50-58 supra and accompanying text. If the company closes a plant in order to avoid bargaining with a union, a "runaway shop" situation exists. See C. MORrus, supra note 9, at 122; Bliss, supra note 27 , at 262-63.

206. In the private sector, labor costs are not only greater than nonlabor payments per unit, but also lave risen at a faster rate than nonlabor payments since 1950. See Current Labor Statisvics, 103 MONTHLY LAB. REv. 95 (1980). As one noted authority stated: "Labor cost is the single most inportant component of price, and in recent years it has constituted about $62-1 / 2 \%$ to $65 \%$ of price. As a consequence, there is a fairly close correlation over time between clanges in unit labor costs and clianges in prices." G. BLOOM \& H. NORTHRUP, ECONOMICS OF LABOR RELATIONS 389 (8th ed. 1977).

207. See notes 10-26 supra and accompanying text.

208. See Brockway Motor Trucks v. NLRB, 582 F.2d 720, $738-39$ (3d Cir. 1978), on remand, 251 N.L.R.B. No. 23, 104 L.R.R.M. 1515 (1980). 
can show any of these circumstances by sufficient evidence, the Board should find that the company has rebutted the presumption that collective bargaining was required prior to closing. ${ }^{209}$

But if the Board finds that an employer has avoided all bargaining and has failed to present evidence sufficient to overcome the presumption in favor of negotiations, the Board should order back pay from the date of the refusal to bargain. ${ }^{210}$ In these cases the company has completely ignored the valid concerns of its employees and their union by terminatimg jobs without giving the employees or their representatives a chance to influence the decision. The employees' imjury, therefore, should be fully compensated.

If, however, the employer does bargain before announcing the closing decision, he should be presumed to have fulfilled his duty to bargain. This presumption would be overcome only by a showing that the bargaining was not in good faith. A key indicator of bad faith would be notice of the closing too late to allow sufficient time for negotiations. Generally a coinpany has an opportumity to engage in timely negotiations since a shutdown decision involves some period of study. Before a company makes its plans final, it should notify and negotiate with the union. ${ }^{211}$ If the company does bargain with the union before it announces the closing decision, the Board should assume, subject to a good-faith inquiry, that the umion's proposals in negotiations were taken into account even though an employer rejected thein and decided to cease operations. The employer's bargaining obligation does not require negotiation to agreement; it requires only good-faith considera-

209. As long as labor-related costs are a part of the reason for the closing, an employer should be required to meet its duty to bargain before the termination decision. See, e.g., Davis v. NLRB, 617 F.2d 1264, 1269-70 (7th Cir. 1980). But cf. NLRB v. First Nat'l Maintenance Corp., 627 F.2d 596 (2d Cir. 1980) (Kearse, J., dissenting in part) (no duty to bargain when closing is caused by mability to agree on management fee), cert. granted, 49 U.S.L.W. 3480 (U.S. Jan. 13, 1981) (No. 80-544).

210. See note 91 supra and accompanying text.

211. There is considerable confusion in Board opinions, see notes 82-89 supra and accompanying text, about when management should inform union officials of the impending decision to close. One recent study suggested that a company is aware of the need to shut down between two and six months in advance of the closing, see Wall St. J., July 22, 1980, at 1, col. 5 (survey by Peter Small \& Assoc.), but others have theorized that one to two weeks is all that is necessary, see Fastiff, supra note 27, at 283. Certainly management's ability to inform a union that it is considering a closing will turn on the circumstances of each case. Management will usually engage in a thorough study before deciding to close. Sce notes 129-30 supra and accoinpanying text. Hence, an employer should notify the union of the possibility of closing and offer to bargain over the decision when it completes its studies and plans. See Swift, supra note 27, at 1148 . Ouly then can the employer ineet its statutory duty to furnish information regarding the closing. See NLRB v. Acme Indus. Co., 385 U.S. 432 (1967). 
tion and discussion to impasse. ${ }^{212}$

Similarly, any charges of surface bargaining should be supported by sufficient evidence. The decision to close raises relatively few issues and the company and union will likely have opposite views. The Board must take into account that there will be little rooin for compromise in these cases, and impose a substantial burden to prove bad-faith bargaining if an employer does in fact negotiate before implementing a closing decision. ${ }^{213}$

Just as a company's negotiations are ineasured by the standard of good faith, so too a union has the obligation of good faith to fulfill its bargaining duty. ${ }^{214}$ If a union violates section 8(b)(3), it can be held hable to an employer for losses caused thereby. ${ }^{215}$ In partial-closing negotiations, an employer's two most significant considerations are confidentiality and speed. With respect to the interest in maintaining confidentiality, it should be remeinbered that an employee is an agent of his employer, ${ }^{216}$ and, as an agent, has a common-law duty not to disclose or use nonpublic material gained in the course of employment for his own profit or to the detriment of his employer. ${ }^{217}$ At common law an-employer could sue for improper disclosure of confidential knowledge as a breach of the duty of loyalty owed by an agent to his

212. "The law is clear that an employer may, after bargaining with the union to a deadlock or impasse on an issue, make 'unilateral changes that are reasonably comprehended within his preimpasse proposals." R. GoRMAN, supra note 9, at 445 (quotimg Taft Broadcasting Co., 163 N.L.R.B. 475, 478 (1967), enforced sub nom. American Fed'n of Television \& Radio Artists v. NLRB, 395 F.2d 622 (D.C. Cir. 1968)). See also Ozark Trailers, Inc., 161 N.L.R.B. 561, 568 (1966); Bi-Rite Foods, Inc., 147 N.L.R.B. 59, 64-65 (1964).

213. Rabin, supra note 27 , at $832-34$. The Board does not generally defer to management's need for flexibility; instead, often it finds bargaining that takes place in partial-closing cases to be insufficient. See First Nat'l Maintenance Corp., 242 N.L.R.B. No. 72, 101 L.R.R.M. 1177 (1979), enforced, 627 F.2d 596 (2d Cir. 1980), cert. granted, 49 U.S.L.W. 3480 (U.S. Jan. 13, 1981) (No. 80-544); The Ohio Brake \& Clutch Corp. 244 N.L.R.B. No. 5, 101 L.R.R.M. 1601 (1979); Walter Pape, Inc., 205 N.L.R.B. 719 (1973).

214. The purpose behind the enactment of section 8(b)(3), 29 U.S.C. $\S 158(b)(3)$ (1976), was to promote "equality and responsibility in bargaining" by making the duty to bargain mutual. H.R. REP. No. 245, 80th Cong., 1st Sess. 31 (1947). See note 7 supra.

215. See, e.g. , NLRB v. ILGWU Local 17, 451 F.2d 1240 (9th Cir. 1971); Graphic Arts Union Local 280 (Jaines H. Barry Co.), 235 N.L.R.B. 1084 (1978), enforced, 596 F.2d 904 (9th Cir. 1979); Umited Bhd. of Carpenters Local 964, 181 N.L.R.B. 948 (1970), enforced, 447 F.2d 643 (2d Cir. 1971); Southern Cal. Pipe Trades, Dist. Council No. 16, 167 N.L.R.B. 1004 (1967), enforced, 449 F.2d 668 (9th Cir. 1971).

216. Restatement (Second) of Agency § 2, Comment d; § 220, Comment g (1957).

217. The agency relationship between an employer and an einployee is a "fiduciary relation." Id. $\S 1$. As fiduciary, the agent has a duty not to reveal or use confidential information. $4 \mathrm{~A}$. SCotT, The Law of Trusts § 505 (1967); W. Sell, Agency $\$ 136$ (1975); Restatement (SecOND) OF AGENCY $\S 395$ (1957). 
principal. ${ }^{218}$ Certainly a union, as the employees' collective bargaining agent, can stand in no better stead than the workers it represents. The only reason an employer ordinarily discloses material about a possible closing to the union is the requirements of the NLRA. For a union to reveal this information, which it has learned only because of the employer's duty to bargam, and which it knows is confidential, would be the antithesis of good faith bargaining. Because the NLRA preempts state law, there is no common-law action for disclosure of labor negotiations data. ${ }^{219}$ Therefore, to provide protection, the Board should find that such conduct violates section $8(b)(3) .220$

Likewise, a union bargaining over the decision to close a plant must be sensitive to the needs of management when time is of the essence. To allow a umion in such instances to delay discussions unreasonably would be an unfair burden on the einployer. When it can be proved that a union has unjustifiably prolonged negotiations over a partial shutdown, the Board should find bad-faith bargaining in violation of section 8(b)(3). Moreover, the Board should hold the union responsible for the foreseeable consequences of its acts. 221 This would ensure that unions recognize the legitimate interests of employers in a partial-closing case, just as coinpanies must respect the proper concerns of its employees by bargaining over the closing decision. If management knew that the law would protect its needs by giving unions an

218. See, e.g., Hunter v. Shell Oil Co., 198 F.2d 485 (5th Cir. 1952); Franke v. Wiltschek, 115 F. Supp. 28 (S.D.N.Y.), affd, 209 F.2d 493 (2d Cir. 1953); Brophy v. Cities Serv. Co., 31 Del. Ch. 241, 244-45, 70 A.2d 5, 7-8 (1949).

219. Since the union's improper disclosure of bargaining data could violate the duty to bargain in good faith under section $8(\mathrm{~b})(3)$ and would not be a purely internal union affair, the NLRA would preempt state regulation of this activity. See Amalgamated Ass'n of Street Employees v. Lockridge, 403 U.S. 274 (1971); San Diego Bldg. Trades Council v. Garmon, 359 U.S. 236 (1959); Broomfield, Preemptive Federal Jurisdiction Over Concerted Trespassory Union Activity, 83 HaRv. L. Rev. 552 (1970); Cox, Labor Law Preemption Revisited, 85 HARv. L. Rev. 1337 (1972); Lesnick, Preemption Reconsidered: The Apparent Reaffirmation of Garmon, 72 ColuM. L. REV. 469 (1972).

220. In Detroit Edison Co. v. NLRB, 440 U.S. 301 (1979), the Supreme Court found that a union could not be ordered to keep information concerning psychological aptitude testing of employees confidential. See note 135 supra. In that case, however, only the employer was charged with an unfair labor practice under section $8(a)(5)$. The Court reasoned that because the union was not a party to the proceeding under section 10(e), 29 U.S.C. $\$ 160$ (e) (1976), it could not be found to have violated a Board order. 440 U.S. at 315-16. This problem would not exist, of course, if an employer named a union as a respondent in a section 8(b)(3) charge for improperly disclosing confidential information about a partial closing. The possibility that such dissemination could violate a union's duty to bargain in good faith was specifically noted in Justice White's dissenting opimion. 440 U.S. at 323 n.3 (White, J., dissenting).

221. As the Supreme Court recently stated, "The Union is responsible for the foreseeable consequences' of its conduct." NLRB v. Retail Store Employees Union Local 1001 (Safeco Title Ins. Co.), 100 S. Ct. 2372, 2377 n.9 (1980); NLRB v. International Union of Operating Eng'rs, 400 U.S. 297, 304-05 (1971); Radio Officers Union v. NLRB, 347 U.S. 17, 46 (1954). 
mcentive to mamtain secrecy and to act promptly when necessary, companies undoubtedly would be inore willing to negotiate over a decision to close part of a business enterprise. Thus the time is ripe for the Supreme Court to determine that an employer's decision to eliminate a financially ailing part of his business, even for legitimate reasons, is subject to the duty to bargain under section $8(a)(5)$.

\section{CONCLUSION}

As the number of business shutdowns increases because of economic difficulties, the issue whether employers inust negotiate with unions over a decision to close a plant assumes greater importance. The present, confused state of the law on this question is unacceptable.222 The Board and the majority of appellate courts differ on the policy underlying the existence of a duty to bargain over a decision to close or move part of a business. Moreover, the Board has inconsistently applied its own doctrine that an employer nuust bargain with a union over a partial-closing decision. And as cases such as Brockway Motor Trucks $v . N L R B$ indicate, appellate courts are divided on this issue as well.

If the concept of collective bargaining is to adhere to the principle of industrial deinocracy that underhes the NLRA, coinpanies should be required to bargain in good faith over partial-closing decisions, even if the motivation for the business termination is purely economic. Suclı a policy may cause some interference with the moveinent of capital that would not be present if management were allowed to decide unilaterally whether an operation should close. Negotiations are appropriate, however, because both management and labor have vital interests at stake in a partial closing. Moreover, the risk of a slight loss of economic efficiency is outweighed by the substantial gains that may occur froin the collective bargaining process if the parties are able to keep the business intact. The salutary purpose of collective negotiations in reducing industrial strife requires that this option be given to eniployees when their jobs are at stake.

222. On the court of appeals' remand of Brockway Motor Trucks v. NLRB, 582 F.2d 720 (3d Cir. 1978), the Board was presented with an excellent opportunity to clarify its approach to the duty of an employer to bargain over a partial closing. The Board noted that the Third Circuit had "declined to adopt what it regarded as the Board's per se rule requiring bargaining whenever a partial closure is based on economic reasons." Brockway Motor Trucks, 251 N.L.R.B. No. 23, 104 Lab. Rel. Rep. 1515, 1516 (1980). Rather than explaining whether this was actually the Board's position, the Board simply stated that it was "[a]ccepting the [Third Circuit's] analysis as the law of the case." Id. The Board did not intimate whether it agreed with the Third Circuit's rationale. Rather than elucidating the law in the area, the Board has thus only further confused its position. 
This article recommends the use of rebuttable presumptions concerning the existence and fulfillment of bargaining obligations to protect the legitimate concerns of management and employees in a partialclosing case. This would provide a rule that could be easily applied by management, labor organizations, and employees, and would also allow flexibility so that the circumstances of each case could be exannined to determine the extent of the duty to bargain.

It is paramount that the NLRB and the courts of appeals adopt uniform guidelines concerning when the duty to bargain exists in a partial-closimg situation. Under the differing standards the Board and the courts use today, it is impossible for counsel to advise conipanies, unions, or employees adequately about the duty to bargain. The Board and the courts, as administrators of the labor laws, should provide a reasonable set of rules concerning partial shutdowns under which all parties can operate. 
